Cochrane Database of Systematic Reviews

\title{
Cardiac rehabilitation for people with heart disease: an overview of Cochrane systematic reviews (Review)
}

Anderson L, Taylor RS

Anderson L, Taylor RS.

Cardiac rehabilitation for people with heart disease: an overview of Cochrane systematic reviews.

Cochrane Database of Systematic Reviews 2014, Issue 12. Art. No.: CD011273.

DOI: 10.1002/14651858.CD011273.pub2.

www.cochranelibrary.com 
TABLE OF CONTENTS

ABSTRACT 1

PLAIN LANGUAGE SUMMARY

BACKGROUND

OBJECTIVES

METHODS

RESULTS

Figure 1.

DISCUSSION

AUTHORS' CONCLUSIONS

ACKNOWLEDGEMENTS

REFERENCES

ADDITIONAL TABLES

APPENDICES

WHAT'S NEW

HISTORY

CONTRIBUTIONS OF AUTHORS

DECLARATIONS OF INTEREST

SOURCES OF SUPPORT

DIFFERENCES BETWEEN PROTOCOL AND REVIEW

INDEX TERMS

2

3

4

4

6

7

10

11

12

13

17

39

40

40

40

40

41

41

41 
[Overview of Reviews]

\title{
Cardiac rehabilitation for people with heart disease: an overview of Cochrane systematic reviews
}

\author{
Lindsey Anderson ${ }^{1}$, Rod S Taylor ${ }^{1}$ \\ 1Institute of Health Research, University of Exeter Medical School, Exeter, UK
}

Contact: Rod S Taylor, rod.taylor@gla.ac.uk.

Editorial group: Cochrane Heart Group.

Publication status and date: Edited (no change to conclusions), published in Issue 12, 2021.

Citation: Anderson L, Taylor RS. Cardiac rehabilitation for people with heart disease: an overview of Cochrane systematic reviews. Cochrane Database of Systematic Reviews 2014, Issue 12. Art. No.: CD011273. DOI: 10.1002/14651858.CD011273.pub2.

Copyright @ 2014 The Cochrane Collaboration. Published by John Wiley \& Sons, Ltd.

\begin{abstract}
A B S T R A C T
Background

Overviews are a new approach to summarising evidence and synthesising results from related systematic reviews.

\section{Objectives}

To conduct an overview of Cochrane systematic reviews to provide a contemporary review of the evidence for delivery of cardiac rehabilitation, to identify opportunities for merging or splitting existing Cochrane reviews, and to identify current evidence gaps to inform new cardiac rehabilitation systematic review titles.
\end{abstract}

\section{Methods}

We searched The Cochrane Database of Systematic Reviews (2014, Issue 10) to identify systematic reviews that addressed the objectives of this overview. We assessed the quality of included reviews using the Revised Assessment of Multiple Systematic Reviews (R-AMSTAR) measurement tool and the quality of the evidence for reported outcomes using the GRADE framework. The focus of the data presentation was descriptive with detailed tabular presentations of review level and trial level characteristics and results.

\section{Main results}

We found six Cochrane systematic reviews and judged them to be of high methodological quality. They included 148 randomised controlled trials (RCTs) in 98,093 participants. Compared with usual care alone, the addition of exercise-based cardiac rehabilitation in low-risk people after myocardial infarction or percutaneous coronary intervention or with heart failure appeared to have no impact on mortality, but did reduce hospital admissions and improved health-related quality of life. Psychological-and education-based interventions alone appeared to have little or no impact on mortality or morbidity but may have improved health-related quality of life. Home- and centre-based programmes were equally effective in improving quality of life outcomes at similar healthcare costs. Selected interventions can increase the uptake of cardiac rehabilitation programmes whilst there is currently only weak evidence to support interventions that improve adherence to cardiac rehabilitation programmes. The quality of the primary RCTs in the included systematic reviews was variable, and limitations in the methodological quality of the RCTs led to downgrading of the quality of the evidence, which varied widely by review and by outcome.

\section{Authors' conclusions}

Exercise-based cardiac rehabilitation is an effective and safe therapy to be used in the management of clinically stable people following myocardial infarction or percutaneous coronary intervention or who have heart failure. Future RCTs of cardiac rehabilitation need to improve their reporting methods and reflect the real world practice better including the recruitment of higher risk people and consideration of contemporary models of cardiac rehabilitation delivery, and identify effective interventions for enhancing adherence to rehabilitation. 


\section{PLAIN LANGUAGE SUMMARY}

Participation in rehabilitation programmes that include regular exercise, can improve the quality of life for people with heart disease

\section{Background}

Cardiac rehabilitation (CR) seeks to improve the function, health-related quality of life and well-being of people with heart disease through a combination of activities, in particular exercise training alongside educational and psychological support. Since the mid-2000s, the number of published Cochrane reviews has grown to six systematic reviews/meta-analyses of CR. These reviews assessed the impact of CR on different types of heart disease (e.g. following a heart attack, heart surgery or heart failure) or different ways of providing CR (e.g. in a hospital- or home-based setting, exercise only programmes or exercise in combination with an educational or psychological intervention or both). The aim of the overview was to review the current CR Cochrane reviews to provide a 'friendly front end' to this 'portfolio' of reviews.

\section{Study characteristics}

We searched for Cochrane reviews that analysed the data from randomised controlled trials (RCT; experiments that randomly allocate participants to one of two or more treatment groups), which looked at the effectiveness of CR in adults with heart disease and compared patient outcomes with a no-exercise control group. This overview summarised the findings from these reviews.

\section{Key results}

We found six high-quality Cochrane reviews that included 148 RCTs in 98,093 people who primarily had experienced a heart attack, had undergone cardiac surgery or had chronic heart failure. The findings of this overview showed important benefits of CR participation that included a reduction in the risk of hospital admissions, as well as improvements in health-related quality of life compared with not undertaking rehabilitation.

\section{Quality of the evidence}

The quality of the RCTs in the included systematic reviews was variable, and limitations in their methodological quality led to downgrading of the quality of the evidence, which varied widely by review and outcome. We make the following recommendations for the future conduct and reporting of systematic reviews of $\mathrm{CR}$.

- The scope of CR reviews needs to reflect current guidelines that recommend that CR should be based on an individually prescribed programme of exercise training with appropriate co-interventions.

- Future CR reviews need to explore the complexity of CR using appropriate approaches to explore the association between intervention characteristics and outcomes across trials.

- Future Cochrane CR reviews need to standardise their methods and reporting. 


\section{B A C K G R O U N D}

\section{Description of the condition}

Heart disease is a broad term used to describe a range of diseases that affect the heart, including diseases of heart blood vessels (coronary artery disease), heart rhythm problems (arrhythmias), heart infections and congenital heart defects. Coronary heart disease (CHD) is the most common type of heart disease and its common symptoms are chest pain (angina) and myocardial infarction (MI). Acute coronary syndrome refers to a range of acute CHD states and includes unstable angina (chest pain at rest), non-ST segment elevation MI (ST segment elevation generally absent) and ST segment elevation infarction (persistent ST segment elevation usually present). CHD can result in difficulties in functionality and performance of everyday activities and can impair sexual function (Racca 2010), contributing to a reduction in health-related quality of life (HRQoL) (Gravely-Witte 2007).

CHD is now considered the leading cause of global mortality. According to the World Health Organization (WHO), CHD accounted for $12.9 \%$ of all deaths (seven million deaths) and $5.8 \%$ of total disability-adjusted life years globally in 2011 (WHO 2014). The situation is worse in high-income countries, and it has been estimated that CHD accounted for $24.8 \%$ of all deaths in Europe in 2011 (WHO 2014). However, despite the overall increase in CHD burden in high-income countries, age-adjusted mortality for this disease is declining and over half of people diagnosed now survive (Allender 2008). This is driven largely by preventive interventions, treatments to prevent death during an acute disease manifestation and rehabilitation interventions that prolong survival (Gaziano 2010). Conversely, morbidity is rising, with an increasing number of survivors of MI (Mathers 2008), and an associated number of cases of chronic heart failure (HF) (Kostis 1997).

The most common cause of HF is CHD. Non-ischaemic causes of $\mathrm{HF}$ include hypertension and atrial fibrillation. HF is a complex clinical syndrome that results from any structural or functional impairment of ventricular filling or ejection of blood. It has been increasingly recognised that HF has two sub-categories: 1 . impaired left ventricular contraction, which results in a reduced ejection fraction (less than 35\% to 50\%), known as HF with reduced ejection fraction (HFREF) or 'systolic HF'; and 2. HF with preserved ejection fraction (HFPEF) with an ejection fraction of greater than $35 \%$ to $50 \%$ and also known as 'diastolic HF'. People with HF experience marked reductions in their exercise capacity, which has detrimental effects on their activities of daily living, HRQoL, and their hospital admission rate and mortality (Go 2014). In high-income countries, about $2 \%$ of adults have HF, but in people over the age of 65 years, this increases to $6 \%$ to $10 \%$ (McMurray 2005; Dickstein 2008). The prevalence and incidence of $\mathrm{HF}$ is steadily increasing, with approximately 825,000 new cases annually in the US (Go 2014). HF has a poor prognosis, with $30 \%$ to $40 \%$ of people diagnosed dying within one year, although thereafter the mortality is less than $10 \%$ per year (Cowie 2000; Hobbs 2007). However, as with CHD, survival after HF diagnosis has also improved (Go 2014), and in the UK there is evidence of a trend of improved prognosis, with the six-month mortality rate decreasing from $26 \%$ in 1995 to $14 \%$ in 2005 (Mehta 2009).

\section{Description of the interventions}

Many definitions of cardiac rehabilitation (CR) have been proposed. The following definition encompasses the key concepts of $C R$ : "The coordinated sum of activities required to influence favourably the underlying cause of cardiovascular disease, as well as to provide the best possible physical, mental and social conditions, so that the patients may, by their own efforts, preserve or resume optimal functioning in their community and through improved health behaviour, slow or reverse progression of disease" (BACPR 2012). While exercise training is the foundation of $C R$, it is recommended that 'comprehensive' programmes also include education (e.g. provision of information about a healthy lifestyle) and psychological intervention (e.g. counselling to reduce stress). CR has many of the characteristics of a 'complex intervention' as defined by in the Medical Research Council 2008 guidance for developing and evaluating complex interventions, that is, 1. number of interacting components, 2. number and difficulty of behaviours required by people delivering or receiving the intervention, 3. number and variability of outcomes and 4. degree of flexibility or tailoring of the intervention permitted (nonstandardisation/reproducibility) (Craig 2008).

Patient education is the process by which health professionals impart information to patients that will alter their health behaviours or improve their health status (Koongstvedt 2001). There is substantial variation in the delivery of patient education for cardiac patients; it may be classroom- or home-based, group or individual, tailored or generic. Duration and reinforcement of education also differs between programmes. Some programmes are developed according to validated educational theory and by trained professionals while others are delivered by peers.

Interventions that specifically aim to influence psychological or psychosocial outcomes are varied and may range from organisational efforts to improve patient communication and support (e.g. Jolly 1998), to empirically supported psychotherapies used to target diagnosed psychopathology in cardiac patients (e.g. Black 1998). Furthermore, psychological/psychosocial interventions may incorporate other elements of CR such as diet and lifestyle advice, or exercise. In some cases, the intervention may be described as 'psychological' only to the extent that psychological techniques are used to further other treatment goals.

The patient groups routinely recommended for $C R$ include people with post-MI, post-revascularisation procedure and HF. Traditionally, CR programmes have been offered in a supervised centre-based setting. However, many people do not receive rehabilitation (Bethell 2008), and with uptake of CR for both CHD and HF currently at sub-optimal levels (Tierney 2011; Dalal 2012; NICE 2013), home-based CR programmes have been increasingly introduced to widen access and participation. In addition to uptake, maintaining longer-term adherence to $\mathrm{CR}$ is also a key challenge (Daly 2002; Moore 2003), and therefore, interventions aimed at improving patient uptake and adherence to $C R$ programmes have been adopted and will be investigated in this overview.

Based on current evidence, national and international guidelines on the management of $\mathrm{CHD}$ and $\mathrm{HF}$ including those by the American College of Cardiology (ACC)/American Heart Association (AHA), European Society of Cardiology (ESC) and National Institute for Health and Care Excellence (NICE, UK), consistently recommend CR 
as an effective and safe intervention (McMurray 2012; NICE 2013; Yancy 2013).

\section{How the intervention might work}

The mechanism by which CR may work depends on the patient group and the component of rehabilitation being considered. Most mechanistic evidence is for exercise training.

For people with $\mathrm{CHD}$, exercise training has direct benefits on the heart and coronary vasculature, including myocardial oxygen demand, endothelial function, autonomic tone, coagulation and clotting factors, inflammatory markers and the development of coronary collateral vessels (Clausen 1976; Hambrecht 2000). However, findings of the original Cochrane review of exercisebased CR for CHD (Jolliffe 2001) supported the hypothesis that reductions in mortality may also be mediated via the indirect effects of exercise through improvements in the risk factors for atherosclerotic disease (i.e. lipids, smoking and blood pressure) (Taylor 2006).

The precise mechanism(s) through which exercise training benefits people with HF remains unclear. One explanation, applicable to people with ischaemic causes of HF, is that exercise training improves myocardial perfusion by alleviating endothelial dysfunction therefore dilating coronary vessels and by stimulating new vessel formation by way of intermittent ischaemia (Piepoli 2004). Indeed, Belardinelli and colleagues have demonstrated that aerobic training improves myocardial contractility and diastolic filling (Belardinelli 1998). One meta-analysis by Haykowsky et al, demonstrated the benefits of exercise training on cardiac remodelling as measured by ejection fraction, end-diastolic volume and end-systolic volume (Haykowsky 2007). Regardless of cause, there are important neurohormonal and musculoskeletal abnormalities in HF. Exercise training may reduce adrenergic tone and increase vagal tone, as suggested by an assessment of variability in heart rate. Skeletal muscle dysfunction and wasting may also respond to exercise training (Piepoli 2004). Hambrecht et al. have demonstrated that regular physical activity in people with HF stimulates vasodilation in the skeletal muscle vasculature (Hambrecht 1998).

The benefits of education and psychological interventions depend on changing people's behaviour including improvements in healthy lifestyle and changes in mood, such as reductions in depression and anxiety.

\section{Why it is important to do this overview}

In 2001, Jolliffe et al. published the first Cochrane review of CR, summarising the evidence of 32 randomised controlled trials (RCTs) in 8440 post-MI and revascularisation patients, and confirming a mortality benefit of exercise-based CR (Jolliffe 2001). With the funding support of the National Institute of Health Research (NIHR, UK), since the mid-2000s, the number of published Cochrane reviews has grown to six systematic reviews/meta-analyses.

- Exercise-based cardiac rehabilitation for coronary heart disease (Heran 2011).

- Exercise-based rehabilitation for heart failure (Taylor 2014b).

- Psychological interventions for coronary heart disease (Whalley 2011).
- Patient education in the management of coronary heart disease (Brown 2011).

- Home-based versus centre-based cardiac rehabilitation (Taylor 2014a).

- Promoting patient uptake and adherence in cardiac rehabilitation (Karmali 2014).

The development of the portfolio of Cochrane reviews has reflected many of the key areas of evolution in the provision of CR and how this model of service delivery can differ across international healthcare jurisdictions. These include the shift from emphasis on exercise therapy alone to comprehensive secondary prevention including risk factor and dietary education and management of psychological factors; the expansion of the population of cardiac patients receiving CR services to include HF; the development of alternative settings of $\mathrm{CR}$ delivery that include home provision in addition to the traditional supervised hospital- or centre-based programmes; and the need to broaden the consideration of the outcomes of CR to inform the needs of healthcare policy makers (e.g. impacts on hospital admission, HRQoL and healthcare costs). This Cochrane CR review portfolio remains dynamic, with three reviews having undergone an update in the last 12 months (Karmali 2014; Taylor 2014a; Taylor 2014b).

The portfolio of Cochrane reviews has played an important role in informing evidence-based policy for CR nationally and internationally, and the reviews have been cited in several key clinical guidelines including those by the ACC/AHA, ESC and NICE, which consistently recommend $C R$ as a safe and effective intervention (Balady 2011; Perk 2012; McKelvie 2013; NICE 2013b; Task Force Members 2013; Yancy 2013).

Overviews of systematic reviews are a new approach to summarising evidence, synthesising results from multiple systematic reviews into a single usable document (Becker 2011). By providing a single synthesis of all relevant evidence in a particular area, overviews may be useful for therapeutic and policy decisionmaking, providing a comprehensive 'friendly front end' to the evidence, so that the reader does not have to assimilate the data from separate systematic reviews. Overviews can also help inform the strategic direction of conduct and structuring of future systematic reviews. For example, the latest version of the Cochrane review of exercise-based CR for CHD included 47 RCTs in over 10,000 participants and may, therefore, benefit from being organised into sub-reviews ('splitting') according to CHD indications (i.e. postMI, revascularisation and angina). Finally, overviews provide an opportunity to identify potential 'evidence gaps' and, therefore, inform areas in which new Cochrane reviews should be prioritised.

\section{OBJECTIVES}

To conduct an overview of Cochrane systematic reviews to provide a contemporary review of the evidence for delivery of cardiac rehabilitation, to identify opportunities for merging or splitting existing Cochrane reviews, and to identify current evidence gaps to inform new cardiac rehabilitation systematic review titles.

\section{METHODS}

We conducted this overview in accordance with the recommendations for Cochrane overviews (Becker 2011). 


\section{Criteria for considering reviews for inclusion}

We initially included the portfolio of six Cochrane CR reviews that were already known to us. In addition, we sought to include any other Cochrane reviews that may inform the aims of this overview including those that assessed the efficiency of CR services or that compared the delivery of CR across different settings.

\section{Types of reviews}

We included Cochrane reviews and protocols currently published in The Cochrane Library that examined the impact of CR. Given the targeted aims of this overview, we did not consider non-Cochrane systematic reviews.

\section{Types of participants}

We included adults aged 18 or over, with heart disease, regardless of aetiology.

\section{Types of interventions}

For the purposes of this review, we defined $C R$ as: exercise with or without education with or without psychological intervention, delivered to people with heart disease, in a hospital community or a home-based setting.

\section{Types of outcome}

\section{Patient-related outcomes}

- Mortality:

- cardiovascular mortality and non-cardiovascular mortality.

- Morbidity:

- MI (total MI, fatal MI and non-fatal MI);

- total revascularisations (coronary artery bypass graft (CABG), percutaneous transluminal coronary angioplasty (PTCA) and re-stenting);

- total hospitalisations (cardiovascular hospitalisations and other hospitalisations);

- HRQoL assessed using validated instruments (e.g. 36-item Short Form (SF-36), EQ5D).

\section{Process-related outcomes}

- Measure of uptake of, or adherence to, CR.

- Costs and cost-effectiveness.

\section{Search methods for identification of reviews}

We searched The Cochrane Database of Systematic Reviews (2014, Issue 10) using the search strategy listed in Appendix 1. We applied no date or language restrictions. Where reviews had been updated, owe sought only the most recent version. We sought full Cochrane reviews or protocols currently published that:

- examined the impact or delivery of CR;

- included adults with heart disease, regardless of aetiology;

- included exercise training interventions either alone or in combination with an educational or psychological intervention or both, delivered in a hospital community or a home-based setting.

\section{Data collection and analysis}

\section{Selection of reviews}

Two authors (LA, RST) independently screened the titles and abstracts of all of the Cochrane systematic reviews identified as a result of the search for inclusion, and coded them as 'retrieve' (eligible or potentially eligible/unclear) or 'do not retrieve'. We retrieved the full-text of selected reviews and two authors (LA, RST) independently screened the full-text and identified reviews for inclusion, and identified and recorded reasons for exclusion of the ineligible reviews. We resolved any disagreements through discussion.

\section{Data extraction and management}

We used standardised data collection forms to extract characteristics of reviews and included studies and outcome data. We piloted these forms on one review included in the overview. One author (LA) extracted review and study characteristics and outcome data from included reviews and a second author (RST) checked all extracted data for accuracy. We resolved disagreements by consensus. If study level information within a published review was unclear or missing, we clarified this by reference to the published reports of the individual RCT. One author (LA) transferred extracted data into the Review Manager 5 (RevMan 2014), and a second author (RST) spot-checked data for accuracy against the systematic reviews.

We extracted the following information from included Cochrane reviews: review objectives or question, search time frame, inclusion criteria (study design, population, intervention, comparator and outcomes), source of funding and stated conflicts of interest of review authors.

We extracted the following characteristics of the RCTs included in each of the Cochrane reviews: number of included trials, year of publication, population, intervention and comparator, primary and secondary outcomes specified and collected, total duration of study, number of study centres and location.

We sought the following outcome data:

- all-cause and disease-specific mortality;

- morbidity: fatal and non-fatal MI; percutaneous coronary intervention ( $\mathrm{PCl}$ ); hospitalisation: overall and disease-specific;

- HRQoL assessed using validated instruments (e.g. SF-36, EQ5D);

- measures of uptake of, or adherence to, CR; and

- costs and cost-effectiveness.

We did not re-assess the risk of bias of included studies within reviews, but instead reported according to the review authors' assessment using The Cochrane Collaboration 'Risk of bias' tool (in accordance with the Cochrane Handbook for Systematic Reviews of Interventions (Higgins 2011). The standard 'Risk of bias' items include: random sequence generation and allocation concealment, description of drop-outs and withdrawals, blinding of outcome assessment and presence of selective reporting. In addition, we sought evidence that the groups were balanced at baseline, that an intention-to-treat analysis was undertaken and that groups received comparable care (apart from the intervention). Where a 'Risk of bias' element was not reported within the review, one author (LA) assessed the original included study publication and a second author (RST) checked the details. 


\section{Assessment of methodological quality of included reviews}

\section{Quality of included Cochrane reviews}

One author (LA) independently assessed the methodological quality of the included reviews using the 'Revised Assessment of Multiple Systematic Reviews' (R-AMSTAR) measurement tool (Kung 2010), where the 11 domains of the original AMSTAR tool (Shea 2009) were scored between 1 and 4 and the R-AMSTAR total score ranged from 11 to 44 . We resolved any disagreements by discussion. A second author (RST) checked the assessment.

\section{Quality of evidence in included reviews}

One author (LA) used GRADEProfiler software to assess the quality of evidence for outcomes reported in, and extracted from, each of the reviews (GRADEpro 2008), based on the following factors: indirectness of evidence, unexplained heterogeneity, publication bias, risk of bias due to study design limitations and imprecision of results (Balshem 2011). A second author (RST) checked the assessment.

\section{Assessment of bias in conducting the overview}

We conducted the overview according to the published protocol and we have reported any deviations from it in the Differences between protocol and review section of this overview.

\section{Data synthesis}

The unit of analysis for this overview is the systematic reviews (and not individual trials). The focus of the data presentation was descriptive, with detailed tabular presentations of the extracted review- and trial-level information outlined above. We conducted no de novo data analysis of trial-level outcomes for this overview. We have tabulated review-level summaries for all the outcomes listed above from each of the included reviews. Where outcomes were meta-analysed within a review, we extracted and reported pooled effect sizes. Where no quantitative pooling of effect sizes was reported, or where outcomes were reported descriptively by single studies, we reported these results by vote counting (Bushman 1984), or using standardised language indicating direction of effect and statistical significance. For continuous outcomes, we summarised data using the standardised mean difference (SMD) or mean difference (MD) with 95\% confidence interval $(\mathrm{Cl})$ as reported in the included reviews. For dichotomous outcomes, we presented the risk ratio (RR) or odds ratio (OR) and $95 \% \mathrm{Cl}$ as appropriate.

Due to the heterogeneity of populations, interventions and outcomes in the included systematic reviews, we did not seek to compare either $C R$ interventions directly across reviews (e.g. exercise $\mathrm{CR}$ versus education for $\mathrm{CHD}$ ) or to compare interventions across review populations (e.g. exercise $\mathrm{CR}$ for $\mathrm{CHD}$ versus exercise $\mathrm{CR}$ for HF). For this reason, we did not attempt to compare outcome results across trials using indirect network meta-analysis methods.

\section{RES U LTS}

\section{Identification of reviews}

Figure 1 summarises the review selection process in a flow diagram. Our database search yielded 92 titles from which we identified one published Cochrane review (in addition to the previously identified six reviews) and four Cochrane review protocols that we judged to meet the inclusion criteria. On review of the full text, we excluded the published Cochrane review (Hulzebos 2012), as it evaluated physical therapy with an exercise component for elective cardiac surgery patients and included only one RCT of exercise training, while the other RCTs assessed inspiratory muscle training (Appendix 2). We judged the four Cochrane protocols to meet the inclusion criteria (see Appendix 3). The remainder of this overview focused on presenting the six Cochrane CR reviews. 
Figure 1. Study flow diagram.

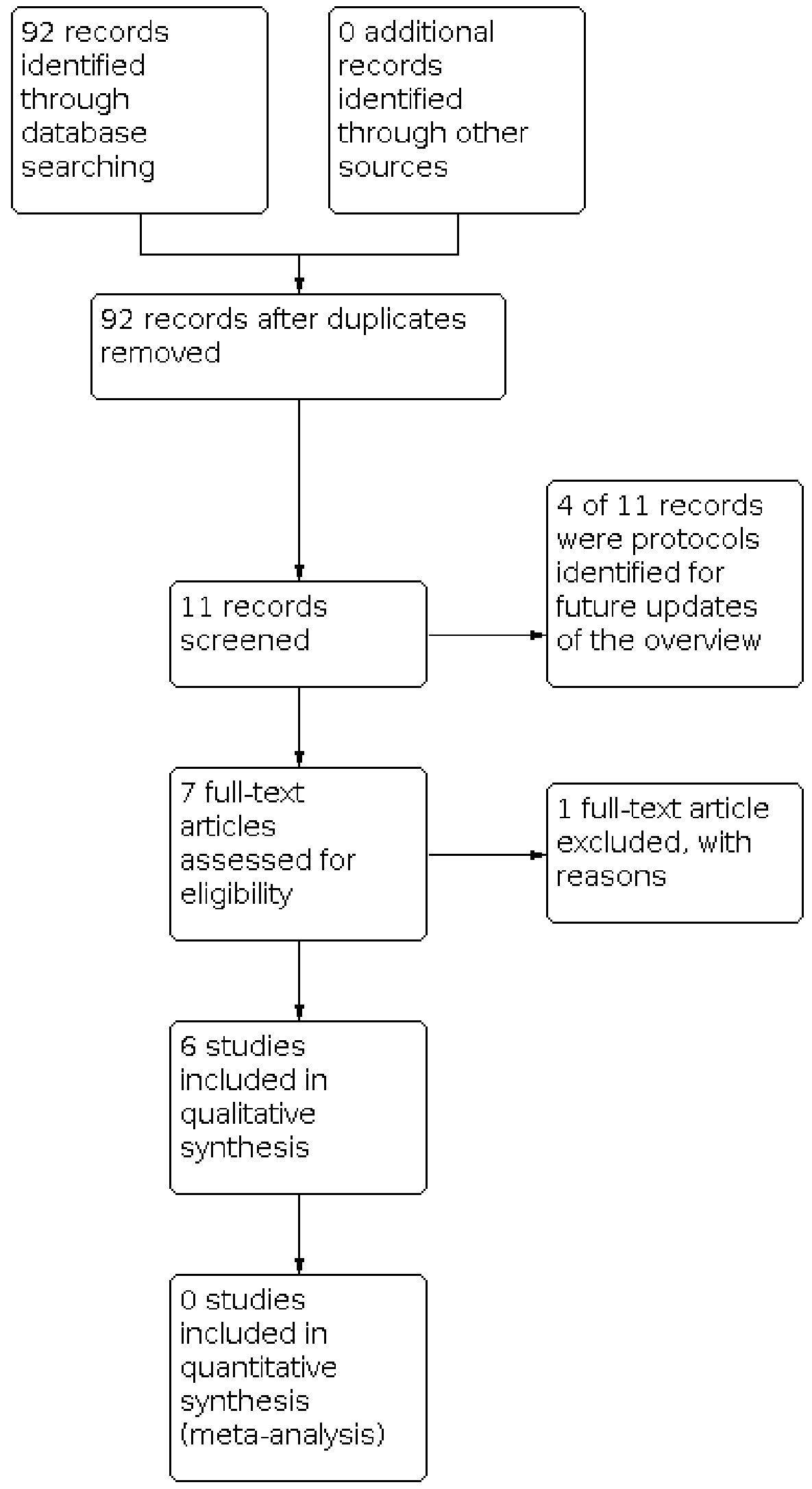




\section{Description of included reviews}

The characteristics of the six included Cochrane reviews are summarised in Table 1 and included RCTs are summarised Table 2.

All included reviews ran searches from the inception of the electronic databases to 2013, and were published between 2011 and 2014. In all reviews, searches were limited to an RCT design and in three cases the inclusion was limited to RCTs with follow-up of six months or longer (Brown 2011; Heran 2011; Taylor 2014b). In total, the included reviews contained 148 RCTs and 97,486 participants. Four RCTs were included in more than one review (Stern 1983; Miller 1984; PRECOR 1991; Lisspers 1999). Most included RCTs were published since the mid-1990 (1970 to 1979: 4 RCTs; 1980 to 1989 : 16 RCTs; 1990 to 1999: 40 RCTs; 2000 to 2009: 72 RCTs, 2010 and later: $16 \mathrm{RCTs}$ ). The median sample size of RCTs ranged widely from only 16 participants (Duncan 2003) to 46,606 participants (Esposito 2008). Most RCTs were undertaken in either Europe (69\%) or North America (35\%) and were mainly single centre (79\%).

\section{Search methods}

All six reviews searched the Cochrane Central Register of Controlled Trials (CENTRAL), MEDLINE, MEDLINE In-Process, EMBASE and CINAHL. In addition, four of the reviews searched PsycINFO (Brown 2011; Heran 2011; Karmali 2014; Taylor 2014a). Three reviews also undertook searches for ongoing RCTs using trial registers (International Standard Randomized Controlled Trial Number (ISRCTN) registry (www.controlled-trials.com) and ClinicalTrials.gov (clinicaltrials.gov/)) and all reviews searched for additional RCTs by manually checking the reference lists of included studies.

\section{Participants}

The types of participants included in this overview varied between reviews. The scope of two reviews included all adults with heart disease, regardless of indication (Karmali 2014; Taylor 2014a), three reviews were limited to people with $\mathrm{CHD}$ (post-MI and $\mathrm{PCI}$ ) (Brown 2011; Heran 2011; Whalley 2011), and one review was limited to HF (Taylor 2014b). Although $78 \%$ of the RCTs that reported gender included women, the median proportion of men included in RCTs ranged from $60 \%$ to $88 \%$ across reviews. The mean age of participants in RCTs ranged from 46 to 87 years.

\section{Interventions}

Two of the reviews included exercise training or exercise training alongside other interventions that included education or psychological support or both (Heran 2011; Taylor 2014b. One review focused on psychological interventions (Whalley 2011), although it included several RCTs that also incorporated an educational component. One review included only RCTs with an educational focus (Brown 2011), one included interventions to increase the uptake and adherence to CR (Karmali 2014), and one review compared the delivery of CR in home- and centre-based settings (Taylor 2014a).

\section{Outcome measures}

All reviews pre-specified outcome measures that consistently included all-cause mortality and HRQoL. Although all reviews sought morbidity outcomes, the definition and breadth of these outcomes varied across reviews. For example, the review by Heran et al. stated that they sought MI (total, fatal, non-fatal), revascularisations (total, CABG, PTCA, stenting) and hospitalisations (Heran 2011, while the review by Karmali et al. reported "CHD event rates" (Karmali 2014). Four reviews sought economic outcomes (Brown 2011; Heran 2011; Taylor 2014a; Taylor 2014b), and two reviews reported collected uptake or adherence data (Karmali 2014; Taylor 2014a).

\section{Data analysis}

Five of the six reviews included meta-analyses of mortality and morbidity outcomes. The review by Karmali et al. pre-stated that heterogeneity (participants, interventions and outcomes), together with the small number of studies identified, precluded undertaking meta-analysis (Karmali 2014). Given the heterogeneity in measures, only one review used meta-analysis to pool HRQoL data across RCTs (Taylor 2014b), the other reviews used a descriptive or vote counting approach to summarise outcomes. This was also the case for uptake and adherence and economic outcomes. Two of the reviews undertook meta-regression analyses to explore how the impact of interventions varied across participant and RCT characteristics (Heran 2011; Taylor 2014b).

\section{Methodological quality of included reviews}

Based on our assessments using the R-AMSTAR tool, all included reviews scored between 35 and 41 (out of a possible maximum of 44) and we deemed them of high methodological quality (see Table 3). None of the reviews stated that journals were hand or manually searched and only one stated that searches were supplemented by consulting books or experts in the field. Two reviews were marked down based on inadequate reporting of the publication status of their included studies. None of the reviews rated the quality of evidence based on a characterised instrument such as GRADE, and while all reviews used The Cochrane Collaboration 'Risk of bias' tool, most were marked down as they did not refer to the quality of included studies in formulating recommendations. The two weaknesses identified across reviews by R-AMSTAR were the lack of an explicit statement on the impact of findings on clinical practice guidelines and the failure to assess the sources of support or conflict of interest in the included RCTs.

\section{Risk of bias of included randomised controlled trials}

All six Cochrane reviews used the core items of The Cochrane Collaboration 'Risk of bias' tool (see Table 4). A consistent finding across reviews was that the included RCTs often did not give enough detail to assess the adequacy of their potential risk of bias. Where details were reported, the quality of RCTs appeared to vary considerably across the risk of bias items. Across all reviews, only a minority of RCTs were judged to be 'adequate' in terms of sequence generation (31\%), sequence concealment (29\%) and outcome blinding (24\%). Other aspects of RCT quality (baseline balance, selective reporting, loss of follow-up, intention-to-treat analysis and groups receiving same intervention) were judged to be better (greater than $50 \%$ of all included RCTs achieving adequacy).

\section{Quality of evidence from randomised controlled trials in included reviews}

The quality of the evidence reported by the RCTs in the included reviews was rated using the GRADE method. The quality of the evidence varied widely (by review and by outcome) and ranged from very low to moderate. See Table 5; Table 6; Table 7; Table 8; and Table 9 for details. 


\section{Effect of interventions}

Table 10 summarises the outcome results across included Cochrane reviews.

\section{Exercise-based cardiac rehabilitation for coronary heart disease (Heran 2011)}

The Heran et al. review undertook database searches up to December 2009 with the inclusion of RCTs with six months or more of follow-up comparing CR with no CR control (Heran 2011). The review included 47 RCTs with 10,794 participants who were mainly post-MI or post- $\mathrm{PCl}$, predominantly men (median $88 \%$ ) and with a median mean age of 55.0 years (see Table 2). CR programmes differed considerably across RCTs in duration (range one to 30 months), frequency (one to seven sessions/week) and session length (20 to 90 minutes/session), and included both exercise-only CR programmes and comprehensive CR programmes (exercise plus psychological or education intervention, or both). We judged this review to be of good methodological quality, with an R-AMSTAR score of 39.

With follow-up of six to 12 months, there was a trend towards a reduction in total mortality (RR $0.82 ; 95 \% \mathrm{Cl} 0.67$ to 1.01 ; low GRADE rating) and no difference was seen between groups in cardiovascular mortality (RR 0.93 ; $95 \% \mathrm{Cl} 0.71$ to 1.21 ; low GRADE rating). However, with follow-up of 12 months or more, $\mathrm{CR}$ reduced overall (RR $0.87 ; 95 \% \mathrm{Cl} 0.75$ to 0.99 ; moderate GRADE rating) and cardiovascular mortality (RR $0.74 ; 95 \% \mathrm{Cl} 0.63$ to 0.87 ; moderate GRADE rating). There was no evidence of a difference in risk of reinfarction or $\mathrm{PCl}$ between $\mathrm{CR}$ and control. Ten of the included studies (2379 participants) reported hospital admissions. In the shorter term (less than 12 months' follow-up), hospital admissions were reduced compared with control (RR $0.69 ; 95 \% \mathrm{Cl} 0.51$ to 0.93 ; moderate GRADE rating) but there was no evidence of a reduction in the longer term (greater than 12 months' follow-up) (RR 0.98; $95 \% \mathrm{Cl} 0.87$ to 1.11 ; low GRADE rating). There was no evidence of heterogeneity of effect across RCTs for any of the mortality or morbidity outcomes. Univariate meta-regression showed no differences in intervention effects across various participant and RCT characteristics in mortality or morbidity outcomes. In seven out of 10 RCTs, there was evidence of a significantly higher level of $\mathrm{HRQ}$ oL with CR than control. Three of the included studies reported data on patient costs, their direct comparison limited by differences in currencies and the time when the studies were conducted.

\section{Exercise-based rehabilitation for heart failure (Taylor 2014b)}

The Taylor et al. review was updated with searches up to March 2013 and included 33 RCTs with six months or more of followup comparing CR with no CR control in 4676 participants with HF (Taylor 2014b). Participants were predominantly men (median $80 \%$ ) with a median age of 60 years, had a reduced ejection fraction (HFREF less than $40 \%$ to $45 \%$ ) and New York Heart Association classification I to III (see Table 2). The exercise regimen ranged widely across RCTs from a session duration of 15 to 120 minutes, from one to seven sessions/week, and from intensity of $40 \%$ to $80 \%$ of maximal heart rate (or equivalent) over a period from one to 120 months and included both exercise-only CR programmes and comprehensive CR programmes (exercise plus psychological or education (or both) intervention). We judged this review to be of good methodological quality, with an R-AMSTAR score of 39 .
There was no evidence of difference in pooled mortality between intervention and controls at six- to 12-month follow-up (RR 0.93; $95 \% \mathrm{Cl} 0.69$ to 1.27 ; low GRADE rating). However, in the six RCTs with more than 12 months' follow-up, there was a trend towards a reduction in all-cause mortality with exercise (RR 0.88; 95\% Cl 0.75 to 1.02; low GRADE rating). Compared with control, exercise training reduced the risk of overall hospitalisation (RR $0.75 ; 95 \% \mathrm{Cl} 0.62$ to 0.92 ; moderate GRADE rating) and HF-specific hospitalisation (RR $0.61 ; 95 \% \mathrm{Cl} 0.46$ to 0.80 ; moderate GRADE rating) although there was no difference in all hospital admissions at beyond 12month follow-up (RR 0.92; 95\% Cl 0.66 to 1.29; very low GRADE rating). Exercise resulted in a clinically important improvement in the Minnesota Living with Heart Failure (MLWHF) questionnaire (MD -5.8 points, -9.2 to -2.4 ; very low GRADE rating) although there was evidence of high levels of statistical heterogeneity $(12=70 \%)$. Univariate meta-regression analysis showed that these benefits in hospitalisation and $\mathrm{HRQ}$ oL were independent of participant characteristics (age, gender, left ventricular ejection fraction), type of CR (exercise only versus comprehensive CR), exercise-based CR regimen, length of follow-up, overall risk of bias, RCT publication date, single versus multicentre RCT or CR setting (home versus centre-based). There was limited evidence to support CR for people with HF with HFPEF (three RCTs, undefined participant number) and when exclusively delivered in a home-based setting (five RCTs, 521 participants).

Three RCTs reported economic data. Although no group differences in costs or outcomes across these three studies achieved statistical significance, two studies indicated CR to be cost-effective (USD1773 per life-year saved; Georgiou 2001), and a mean gain in qualityadjusted life-year (QALY) of 0.03 at an additional mean cost of USD1161 per person (Flynn 2009).

\section{Psychological interventions for coronary heart disease (Whalley 2011)}

The Whalley et al. review undertook searches up to January 2009 with the inclusion of RCTs of psychological interventions compared with usual care in people with a diagnosis coronary artery disease (Whalley 2011). The review included 24 RCTs in 9296 participants who were predominantly low-risk post-MI or $\mathrm{PCI}$, male (median $84 \%$ ) with a median mean age of 57 years (see Table 2). The review authors reported substantial variability in the intensity of treatments offered across RCTs; the mean number of hours spent in treatment was 26.1 hours (2.4 to 96). Included trials applied both psychological-only CR programmes and comprehensive CR programmes (psychological and education interventions).

Most interventions were based on group therapy sessions or comprised a mix of group and individual session; only four RCTs used treatments that were delivered only on an individual basis. We judged the review to be of good methodological quality, with an R-AMSTAR score of 39. There was evidence of a trend towards a reduction in all-cause mortality (RR $0.89 ; 95 \% \mathrm{Cl} 0.75$ to 1.05 ; low GRADE rating) and fewer cardiac deaths with psychological intervention (RR 0.80; 95\% $\mathrm{Cl} 0.64$ to 1.00; low GRADE rating). There were significant effects on occurrence of revascularisation (RR 0.95; $95 \% \mathrm{Cl} 0.80$ to 1.13 ; moderate GRADE rating) and non-fatal reinfarction (RR $0.87 ; 95 \% \mathrm{Cl} 0.67$ to 1.13 ; low GRADE rating). One of seven studies reported superiority in $\mathrm{HRQ}$ oL with psychological intervention compared with usual care. 


\section{Patient education in the management of coronary heart} disease (Brown 2011)

The Brown et al. review undertook searches up to August 2010 with the inclusion of RCTs (with follow-up of six months or more) of patient education interventions compared with usual care (Brown 2011). The review included 13 RCTs in 68,556 participants with HF, stable angina, and post-MI and $\mathrm{PCI}$ who were predominantly male (median 60\%) with a median mean age of 62.0 years (see Table 2). Interventions varied considerably across RCTs, with some providing group sessions, some individualised education and others both. Educational regimen ranged from two clinic visits to a four-week residential stay with 11 months of follow-up sessions. All included trials were limited to educational interventions and did not use other CR interventions of exercise or psychological support. We judged this review to be of good methodological quality, with an R-AMSTAR score of 41 . There was no evidence of a significant difference in total mortality (RR $0.79 ; 95 \% \mathrm{Cl} 0.55$ to 1.13 ; moderate GRADE rating) or morbidity (MI: RR $0.63 ; 95 \% \mathrm{Cl} 0.26$ to 1.48 , low GRADE rating; CABG: $\mathrm{RR} 0.58$; $95 \% \mathrm{Cl} 0.19$ to 1.71 , low GRADE rating; hospitalisation: RR $0.83 ; 95 \% \mathrm{Cl} 0.65$ to 1.07 , moderate GRADE rating). Across the 11 studies that reported $\mathrm{HRQ}$ oL, while there was no consistent difference in HRQoL total or domain score at followup between intervention and control, five RCTs demonstrated statistically significant differences in some domains in favour of intervention. Five RCTs reported healthcare utilisation and costs. Given the small number of included RCTs, the authors deemed meta-regression analysis inappropriate.

\section{Home-based versus centre-based cardiac rehabilitation (Taylor 2014a)}

The Taylor et al. review was updated with searches up to November 2012 and sought to include RCTs comparing home-based and centre-based CR (Taylor 2014a). Home-based CR was defined as "a structured programme with clear objectives for the participants, including monitoring, follow up visits, letters or telephone calls from staff, or at least self-monitoring diaries" and centre-based CR was defined as "based in a variety of settings (e.g. hospital physiotherapy department, university gymnasium, community sports centre)". The review included 17 RCTs in 2172 people with stable angina, $\mathrm{HF}$ and post-MI and $\mathrm{PCl}$ who were predominantly male (median $80 \%$ ) with a median mean age of 60 years (see Table 2). Most RCTs compared comprehensive programmes (i.e. exercise training plus education or psychological (or both) interventions) with the exercise components differing considerably across RCTs in duration (range 1.5 to six months), frequency (one to five sessions per week) and session length (20 to 60 minutes per session). Included trials applied both exercise-only CR programmes and comprehensive $\mathrm{CR}$ programmes (exercise plus psychological or education (or both) intervention). We judged the review to be of good methodological quality, with an R-AMSTAR score of 40 . There was evidence of a difference in mortality at three to 12 months' follow-up between home and centre CR (RR 0.79; 95\% $\mathrm{Cl} 0.43$ to 1.47 ; low GRADE rating). Four studies reported cardiac events, but no pooling of data was possible due to differences in the nature of the reported events. There was no evidence of difference between the two settings in overall or domain HRQoL scores in individual RCTs. Four out of the 14 studies reporting adherence found superior adherence in the home-based compared with centre-based CR setting. There was no consistent difference in the healthcare costs associated with the two forms of CR, although difference in currencies and timing of studies meant that it was not possible to compare costs directly across studies. In three of the four studies, the healthcare costs associated with CR were lower for the home-based than centre-based programmes, although this was significantly lower in only one study (GBP170 per participant versus GBP200 per participant; difference of -GBP $30,95 \% \mathrm{Cl}-45$ to -12 ; P value $<0.0001$; Dalal 2007). Jolly et al. found that home-based $C R$ was more expensive than centre-based CR (GBP198 per participant versus GBP157 per participant; P value $<0.05$; Jolly 2007), although the costs of two would be the same if participant travel costs and travel time were included. Given the small number of included RCTs, the authors deemed meta-regression analysis inappropriate.

\section{Promoting participant uptake and adherence in cardiac rehabilitation (Karmali 2014)}

The Karmali et al. review was updated with searches up to January 2013 and sought to include RCTs of interventions to increase CR uptake (participants attendance or enrolment in CR programmes) or adherence (extent to which the participant's behaviour concurred with the advice given by health professional, e.g. to attend CR meetings or to undertake independent exercise) (Karmali 2014). The review included 18 RCTs in 2505 participants with HF, stable angina, and post-MI and $\mathrm{PCl}$ who were predominantly male (median 84\%). We judged this review to be of good methodological quality, with an R-AMSTAR score of 35 . Meta-analysis and metaregression was not undertaken due to heterogeneity in outcome definition across RCTs. Of the 10 RCTs (1658 participants) evaluating the effectiveness of interventions to increase uptake of $C R$, eight reported higher rates of CR uptake in the intervention group (range $11 \%$ to $46 \%)$. Uptake was variously defined in these studies as enrolment in $\mathrm{CR}$, attendance at a variety of time points or by number of sessions over a 12-week period. Interventions that improved uptake of CR included: structured nurse- or therapist-led contacts, early appointments after discharge, motivational letters, gender-specific programmes and intermediate-phase programmes for elderly people. Three out of eight RCTs (1167 participants) found significant improvements in adherence to CR although there was no evidence of an improvement in HRQoL. Interventions that improved adherence included self monitoring of activity, action planning and tailored counselling by CR staff. Although data were limited, there was no evidence of a difference in mortality or morbidity with uptake or adherence interventions. No RCTs reported on costs or cost-effectiveness.

\section{DISCUSSION}

\section{Summary of main results}

CR programmes have become an integral part of the standard of care for people with heart disease. The scope of contemporary $\mathrm{CR}$ has shifted from exercise interventions alone to more comprehensive secondary prevention programmes that include risk factor education and psychological support. This overview identified six Cochrane systematic reviews of RCTs that have assessed the outcomes of various aspects of the delivery of $C R$ and its component interventions. The key outcome findings of our overview were:

- exercise-based $\mathrm{CR}$ in low-risk people with $\mathrm{HF}$ and after MI or $\mathrm{PCl}$, is safe, with no increase in short-term mortality, and effective in terms of reductions in the risk of hospital admission and improvements in patient HRQoL, compared with control. While there was considerable evidence of heterogeneity 
across included primary studies in both the characteristics of the evaluated CR programmes and also across the included participants, the outcome benefits of CR in terms of HRQoL and reduced hospitalisation appeared to be independent of these programme and participant characteristics;

- psychological-based and education-based interventions alone appear to have little or no impact on mortality or hospitalisation, but may improve HRQoL of people with CHD in comparison with usual care alone;

- home-based and centre-based programmes seem to be equally effective in improving the outcomes of exercise-based CR in low-risk people after MI or post-revascularisation or with HF. Healthcare costs of the two forms of CR were similar, presumably as any cost reduction in delivering the intervention in the home was offset by the associated costs of delivering individual nursing care; and

- uptake of CR programmes was only weakly supported by interventions designed to improve adherence to $C R$ programmes.

\section{Overall completeness and applicability of evidence}

There are a number of published non-Cochrane systematic reviews of CR (Oldridge 1988; O'Connor 1989; Brown 2003; Piepoli 2004; Haykowsky 2007; Hwang 2009; Lawler 2011; Oldridge 2012). Given that our focus was Cochrane reviews, we acknowledge that this overview cannot be regarded as an all-inclusive summary of the evidence base for CR. However, by focusing on high-quality Cochrane reviews, we believe this overview potentially provides a least biased estimate of the impact of CR.

\section{Quality of the evidence}

The included Cochrane systematic reviews were generally of high quality and three had been updated with a literature search since 2011 (Karmali 2014; Taylor 2014a; Taylor 2014b. However, the quality of the primary RCTs in the included systematic reviews was variable. The main sources of bias in the primary studies were inadequate reporting of allocation concealment and randomisation methods and lack of outcome blinding. These limitations in the methodological quality led to the downgrading of the quality of the evidence, which varied by outcome within each review. Other reasons for downgrading the evidence included heterogeneity or inconsistency of effect, and imprecision of results. Another potential source of inconsistency that was not reported in the reviews was differential use of outcome data by RCTs (i.e. some studies analysed only post-interventional data while others measured pre-post change).

\section{Potential biases in the overview process}

This overview included RCTs conducted between 1974 and 2013. During this time, there have been major advances in medical management, such as the increased use of statins since the mid-1990s. Indeed, it has been hypothesised that major advances in post-MI medical management since the mid-2000s has led to a reduction in the incremental effect on mortality of $\mathrm{CR}$ compared with usual care alone (Taylor 2012). This decrement in mortality benefit associated with CR was supported by the Rehabilitation After Myocardial Infarction Trial (RAMIT), which was published after the search cut of the exercise-based CR for CHD Cochrane review. This trial randomised 1813 participants in 14 hospitals in England and Wales to receive either comprehensive CR or usual care and found no difference in all-cause mortality at two years (RR 0.98; $95 \%$ $\mathrm{Cl} 0.74$ to 1.30 ) or after seven to nine years (RR $0.99 ; 95 \% \mathrm{Cl} 0.85$ to 1.15) (West 2012). This RCT was published after the search cut off of the exercise-based CR for CHD Cochrane review.

A potential strength of an overview is that it can provide an opportunity to undertake indirect comparisons across interventions that might not be included in single systematic reviews using mixed treatment comparisons and network metaanalysis methods (Becker 2011; Mills 2013). In brief, an indirect comparison involves the comparison of two (or more) interventions via one or more common comparator. For example, we may seek to compare the impact of exercise-based interventions and psychological-based interventions via the combination of RCTs of exercise-based intervention versus usual care with RCTs of psychological-based intervention versus usual care. However, for the intervention effect determined using an indirect comparison to be valid and equivalent to the intervention effect measured using a direct comparison, the sets of RCTs used to obtain the indirect comparison need to be sufficiently similar in their characteristics (i.e. patient population, intervention, comparator and outcomes across trials need to be similar - the transitivity assumption) (Cipriani 2013). Given the substantial heterogeneity in the populations of the included CR RCTs, not only between, but also within the included CR systematic reviews, we deemed indirect comparisons as inappropriate in the case of this overview. Based on the same reasoning, readers of this overview need to apply considerable caution in taking an informal indirect comparison approach and comparing the results for a given outcome across reviews.

\section{Agreements and disagreements with other studies or reviews}

In 2012, Oldridge undertook an overview of meta-analyses of CR in people with CHD (Oldridge 2012. Given that this overview included both Cochrane and non-Cochrane meta-analyses published since 2000 , there is considerable overlap in findings and conclusions with the present overview. One important difference between the two overviews is the conclusion of a reduction in all-cause and cardiovascular mortality with CR in the overview by Oldridge (Oldridge 2012). This mortality benefit was primarily seen in three non-Cochrane meta-analyses (Taylor 2004; Clark 2005; Lawler 2011), while the Cochrane review found a statistically significant reduction in all-cause and cardiac mortality only at follow-up of greater than 12 months (Heran 2011).

\section{AUTHORS' CONCLUSIONS}

\section{Implications for practice}

The evidence compiled by this overview supports current international clinical guidelines that state that the addition of cardiac rehabilitation (CR) to medical management is effective (improving health-related quality of life (HRQoL) and reducing the risk of future hospitalisations) and safe (with no increase in shortterm mortality), compared with a no exercise training control, for clinically stable participants following myocardial infarction (MI) or percutaneous coronary intervention $(\mathrm{PCl})$ or who have heart failure (Balady 2011; Perk 2012; McKelvie 2013; Task Force Members 2013; NICE 2013; Yancy 2013). Future randomised controlled trials (RCTs) of CR need to improve their reporting methods and better reflect the real world practice including the recruitment of higher- 
risk participants and consideration of contemporary models of CR delivery, and identify effective interventions for enhancing adherence to rehabilitation.

\section{Implications for research}

Based on this overview, and taking account of recent guidelines for the conduct of systematic review of complex interventions (Weir 2012; Petticrew 2013), we make the following recommendations for the conduct of future CR systematic reviews:

- Scope of reviews: the scope of CR reviews needs to reflect current guidelines that consistently recommend that $C R$ should be based on an individually prescribed programme of exercise training with appropriate co-intervention including psychological or educational interventions (BACPR 2012; McMurray 2012; NICE 2013; Yancy 2013).

- Handling of the complexity of CR: given that $C R$ is a complex intervention, a key challenge of systematic reviews of $C R$ is taking account of the potential heterogeneity in CR interventions (content and methods of delivery) and the population of people who receive CR. Future reviews of $\mathrm{CR}$ need to explore this complexity using approaches that include stratification ('splitting') of outcome results by patient indication (e.g. post-MI versus post-PCI) or intervention type (i.e. exercise training only versus comprehensive CR interventions); reporting within RCT subgroup analyses; and use of metaregression to explore the association between intervention characteristics and outcomes across trials. Consideration should also be given to the appropriate use of indirect comparison methods (Bucher 1997) in reviews or broadening the inclusion criteria of reviews to include active comparator arms of RCTs that would allow assessment of the comparative effectiveness of different CR interventions (or both). Theorybased approaches to systematic reviews of CR are also needed (Gardner 2010).

- Consistency in review conduct and reporting: to facilitate comparison across CR systematic reviews and the efficient future update of this overview, future Cochrane CR reviews need to standardise their methods and reporting, including the reporting of included RCT characteristics, risk of bias assessment criteria, outcomes and evidence synthesis approaches.
In addition to the current Cochrane $\mathrm{CR}$ reviews that are in protocol and title stage (Devi 2011; Euler 2013; Sibilitz 2013; Mechta-Nielsen 2014; Risom 2014), consideration should be given to new Cochrane titles to fill the CR evidence gaps identified by this overview, including 'exercise-based CR for post-cardiac transplantation' and 'exercise-based CR for congenital heart disease'.

This overview also highlights several potential areas for consideration in the conduct of future RCTs of CR. RCT recruitment criteria need to reflect the real world of $C R$ delivery better, which includes people at higher risk who are older, female and from a broader range of ethnicities and socio-economic groups. Reporting of trial methods should be improved, with greater details of the process of randomisation and outcome blinding, more precise description of the intervention, and consistency in the collection and reporting of outcome measures, including the use of validated HRQoL instruments, cardiac-related events, re-admissions and costs. Finally, as noted by Clark and colleagues, future RCTs need to "open the black box" of CR better (Clark 2013. In other words, to determine the incremental benefits of the various components of $C R$ requires future RCTs to provide more precise descriptions of their CR interventions so these comparisons can be more explicitly and reliably undertaken in future systematic reviews. One publication provides researchers and clinicians with a framework to improved reporting of intervention detail (Hoffmann 2014). In addition, the design of future RCTs should consider 'head-to-head' comparisons of different combinations of CR interventions (e.g. an 'exercise-only' CR intervention compared with 'exercise plus' CR intervention).

\section{ACKNOWLEDGEMENTS}

We are grateful for the help of Nicole Martin at the Cochrane Heart Group, for her help in developing the search strategy for this overview. We are extremely grateful to our external reference group members (Dr Mike Knapton, Prof Gill Furze, Dr Neil Smart, Prof Patrick Doherty, Dr Ann-Dorthe Zwisler, Prof Neil Oldridge, Dr Phil Adams, Dr Christopher O'Conner, Dr Juan Pablo-Casas and Dr Mark Huffman) for their invaluable advice and support in the preparation of this manuscript. 


\section{RE F E R E N C E S}

\section{References to included reviews}

\section{Brown 2011}

Brown JP, Clark AM, Dalal H, Welch K, Taylor RS. Patient education in the management of coronary heart disease. Cochrane Database of Systematic Reviews 2011, Issue 12. Art. No: CD008895. [DOI: 10.1002/14651858.CD008895.pub2]

\section{Heran 2011}

Heran BS, Chen JM, Ebrahim S, Moxham T, Oldridge N, Rees K, et al. Exercise-based cardiac rehabilitation for coronary heart disease. Cochrane Database of Systematic Reviews 2011, Issue 7. Art. No: CD001800. [DOI: 10.1002/14651858.CD001800.pub2]

\section{Karmali 2014}

Karmali K, Davies P, Taylor F, Beswick A, Martin N, Ebrahim S. Promoting patient uptake and adherence in cardiac rehabilitation. Cochrane Database of Systematic Reviews 2014, Issue 6. Art. No: CD007131. [DOI: 10.1002/14651858.CD007131.pub3]

\section{Taylor 2014a}

Taylor RS, Dalal H, Jolly K, Zawada A. Home-based versus centre-based cardiac rehabilitation. Cochrane Database of Systematic Reviews 2014, Issue in press. Art. No: CD007130. [DOI: 10.1002/14651858.CD007130.pub2]

\section{Taylor 2014b}

Taylor RS, Sager VA, Davies EJ, Briscoe S, Coats AJ, Dalal H, et al. Exercise-based rehabilitation for heart failure. Cochrane Database of Systematic Reviews 2014, Issue 4. Art. No: CD003331. [DOI: 10.1002/14651858.CD003331.pub4]

\section{Whalley 2011}

Whalley B, Rees K, Davies P, Bennett P, Ebrahim S, Liu Z, et al. Psychological interventions for coronary heart disease. Cochrane Database of Systematic Reviews 2011, Issue 8. Art. No: CD002902. [DOI: 10.1002/14651858.CD002902.pub3]

\section{References to excluded reviews}

\section{Hulzebos 2012}

Hulzebos EHJ, Smit Y, Helders PPJM, van Meeteren NLU. Preoperative physical therapy for elective cardiac surgery patients. Cochrane Database of Systematic Reviews 2012, Issue 11. Art. No: CD010118. [DOI: 10.1002/14651858.CD010118.pub2]

\section{Additional references}

\section{Allender 2008}

Allender S, Scarborough P, O'Flaherty M, Capewell S. Patterns of coronary heart disease mortality over the 20th century in England and Wales: possible plateaus in the rate of decline. $B M C$ Public Health 2008;8:148.

BACPR 2012

British Association for Cardiovascular Prevention and Rehabilitation. The BACPR standards and core components for cardiovascular disease prevention and rehabilitation, 2nd edition, 2012. www.bacpr.com/resources/46C_BACPR_ Standards_and_Core_Components_2012.pdf (accessed 7 December 2014).

\section{Balady 2011}

Balady GJ, Ades PA, Bittner VA, Franklin BA, Gordon NF, Thomas RJ, et al. Referral, enrolment, and delivery of cardiac rehabilitation/secondary prevention programs at clinical centers and beyond: a presidential advisory from the American Heart Association. Circulation 2011;124(25):2951-60.

\section{Balshem 2011}

Balshem H, Helfand M, Schunemann HJ, Oxman AD, Kunz R, Brozek J, et al. GRADE guidelines: 3 . Rating the quality of evidence. Journal of Clinical Epidemiology 2011;64:401-6.

\section{Becker 2011}

Becker LA, Oxman AD. Chapter 22: overviews of reviews. In: Higgins JPT, Green S (editors). Cochrane Handbook for Systematic Reviews of Interventions Version 5.1.0 [updated March 2011]. The Cochrane Collaboration, 2011. Available from www.cochrane-handbook.org.

\section{Belardinelli 1998}

Belardinelli R, Georgiou D, Ginzton L, Cianci G, Purcaro A. Effects of moderate exercise training on thallium uptake and contractile response to low-dose dobutamine of dysfunctional myocardium in patients with ischemic cardiomyopathy. Circulation 1998;97:553-61.

\section{Bethell 2008}

Bethell H, Lewin R, Evans J, Turner S, Allender S, Petersen S. Outpatient cardiac rehabilitation attendance in England: variability by region and clinical characteristics. Journal of Cardiopulmonary Rehabilitation and Prevention 2008;28(6):386-91.

\section{Black 1998}

Black JL, Allison TG, Williams DE, Rummans TA, Gau GT. Effect of intervention for psychological distress on rehospitalization rates in cardiac rehabilitation patients. Psychosomatics 1998;39:134-43.

\section{Brown 2003}

Brown A, Taylor R, Noorani H, Stone JA, Skidmore B. Exercisebased cardiac rehabilitation programs for coronary artery disease: a systematic clinical and economic review. Canadian Coordinating office for Health Technology Assessment 2003;Technology report 34.

\section{Bucher 1997}

Bucher HC, Guyatt GH, Griffith LE, Walter SD. The results of direct and indirect treatment comparisons in meta-analysis of randomized controlled trials. Journal of Clinical Epidemiology 1997;50:683-91. 


\section{Bushman 1984}

Bushman BJ. Vote-counting procedures in meta-analysis. In: Cooper H, Hedges LV, editors(s). The Handbook of Research Synthesis. New York: Russell Sage Foundation, 1984:193-213.

\section{Cipriani 2013}

Cipriani A, Higgins JP, Geddes JR, Salanti G. Conceptual and technical challenges in network meta-analysis. Annals of Internal Medicine 2013;159:130-7.

\section{Clark 2005}

Clark AM, Hartling L, Vandermeer B, McAlister FA. Meta-analysis: secondary prevention programs for patients with coronary artery disease. Annals of Internal Medicine 2005;143:659-72.

\section{Clark 2013}

Clark AM. What are the components of complex interventions in healthcare? Theorizing approaches to parts, powers and the whole intervention. Social Science \& Medicine 2013;93:185-93.

\section{Clausen 1976}

Clausen JP. Circulatory adjustments to dynamic exercise and effect of physical training in normal subjects and in patients with coronary artery disease. Progress in Cardiovascular Disease 1976;18:459-95.

\section{Cowie 2000}

Cowie MR, Wood DA, Coats AJ, Thompson SG, Suresh V, PooleWilson PA, et al. Survival of patients with a new diagnosis of heart failure: a population based study. Heart 2000;83:505-10.

\section{Craig 2008}

Craig P, Dieppe P, Macintyre S, Michie S, Nazareth I, Petticrew M. Developing and evaluating complex interventions: the new Medical Research Council guidance. BMJ 2008;337:a1655.

\section{Dalal 2007}

Dalal HM, Evans PH, Campbell JL, Taylor RS, Watt A, Read KL, et al. Home-based versus hospital-based rehabilitation after myocardial infarction: a randomized trial with preference arms - Cornwall Heart Attack Rehabilitation Management Study (CHARMS). International Journal of Cardiology 2007;119:202-11.

\section{Dalal 2012}

Dalal HM, Wingham J, Palmer J, Taylor R, Petre C, Lewin R, et al. Why do so few patients with heart failure participate in cardiac rehabilitation? A cross-sectional survey from England, Wales and Northern Ireland. BMJ Open 2012;2:e000787.

\section{Daly 2002}

Daly J, Sindone AP, Thompson DR, Hancock K, Chang E, Davidson P. Barriers to participation in and adherence to cardiac rehabilitation programs: a critical literature review. Progress in Cardiovascular Nursing 2002;17:8-17.

\section{Devi 2011}

Devi R, Igbinedion E, Powell J, Singh S, Rees K. Internet based interventions for the secondary prevention of coronary heart disease. Cochrane Database of Systematic Reviews 2011, Issue 10. Art. No: CD009386. [DOI: 10.1002/14651858.CD009386]

\section{Dickstein 2008}

Dickstein K, Cohen-Solal A, Filippatos G, McMurray JJ, Ponikowski P, Poole-Wilson PA, et al. ESC guidelines for the diagnosis and treatment of acute and chronic heart failure 2008: the Task Force for the diagnosis and treatment of acute and chronic heart failure 2008 of the European Society of Cardiology. Developed in collaboration with the Heart Failure Association of the ESC (HFA) and endorsed by the European Society of Intensive Care Medicine (ESICM). European Journal of Heart Failure 2008;10:933-89.

\section{Duncan 2003}

Duncan K, Pozehl B. Effects of an exercise adherence intervention on outcomes in patients with heart failure. Rehabilitation Nursing 2003;28:117-22.

\section{Esposito 2008}

Esposito D, Brown R, Chen A, Schore J, Shapiro R. Impacts of a disease management program for dually eligible beneficiaries. Health Care Financing Review 2008;30:27-45.

\section{Euler 2013}

Euler U, Wegewitz UE, Schmitt J, Adams J, van Dijk JL, Seidler A. Interventions to support return-to-work for patients with coronary heart disease. Cochrane Database of Systematic Reviews 2013, Issue 9. Art. No: CD010748. [DOI: 10.1002/14651858.CD010748]

\section{Flynn 2009}

Flynn KE, Pina IL, Whellan DJ, Lin L, Blumenthal JA, Ellis SJ, et al. Effects of exercise training on health status in patients with chronic heart failure: HF-ACTION randomized controlled trial. JAMA 2009;301:1451-9.

\section{Gardner 2010}

Gardner B, Whittington C, McAteer J, Eccles MP, Michie S. Using theory to synthesise evidence from behaviour change interventions: the example of audit and feedback. Social Science \& Medicine 2010;70:1618-25.

\section{Gaziano 2010}

Gaziano TA, Bitton A, Anand S, Abrahams-Gessel S, Murphy A. Growing epidemic of coronary heart disease in low- and middle-income countries. Current Problems in Cardiology 2010;35:72-115.

\section{Georgiou 2001}

Georgiou D, Chen Y, Appadoo S, Belardinelli R, Greene R, Parides MK, et al. Cost-effectiveness analysis of long-term moderate exercise training in chronic heart failure. American Journal of Cardiology 2001;87:984-8.

\section{Go 2014}

Go AS, Mozaffarian D, Roger VL, Benjamin EJ, Berry JD, Blaha MJ, et al. Heart disease and stroke statistics - 2014 update: a report from the American Heart Association. Circulation 2014;129:e28-e292. 


\section{GRADEpro 2008 [Computer program]}

GRADE Working Group GRADEprofiler. Version 3.2 for Windows. Brozek J, Oxman A, Schünemann H. GRADE Working Group, 2008.

\section{Gravely-Witte 2007}

Gravely-Witte S, De Gucht V, Heiser W, Grace SL, Van Elderen T. The impact of angina and cardiac history on health-related quality of life and depression in coronary heart disease patients. Chronic Illness 2007;3:66-76.

\section{Hambrecht 1998}

Hambrecht R, Fiehn E, Weigl C, Gielen S, Hamann C, Kaiser R, et al. Regular physical exercise corrects endothelial dysfunction and improves exercise capacity in patients with chronic heart failure. Circulation 1998;98(24):2709-15.

\section{Hambrecht 2000}

Hambrecht R, Gielen S, Linke A, Fiehn E, Yu J, Walther C, et al. Effects of exercise training on left ventricular function and peripheral resistance in patients with chronic heart failure: a randomized trial. JAMA 2000;283:3095-101.

\section{Haykowsky 2007}

Haykowsky MJ, Liang Y, Pechter D, Jones LW, McAlister FA, Clark AM. A meta-analysis of the effect of exercise training on left ventricular remodeling in heart failure patients: the benefit depends on the type of training performed. Journal of the American College of Cardiology 2007;49:2329-36.

\section{Higgins 2011}

Higgins JPT. Chapter 8: Assessing risk of bias in included studies. In: Higgins JPT, Green S (editors). Cochrane Handbook for Systematic Reviews of Interventions Version 5.1.0 [updated March 2011]. The Cochrane Collaboration, 2011. Available from www.cochrane-handbook.org.

\section{Hobbs 2007}

Hobbs FD, Roalfe AK, Davis RC, Davies MK, Hare R, Midlands Research Practices Consortium. Prognosis of all-cause heart failure and borderline left ventricular systolic dysfunction: 5 year mortality follow-up of the Echocardiographic Heart of England Screening Study (ECHOES). European Heart Journal 2007;28:1128-34.

\section{Hoffmann 2014}

Hoffmann TC, Glasziou PP, Boutron I, Milne R, Perera R, Moher D, et al. Better reporting of interventions: template for intervention description and replication (TIDieR) checklist and guide. BMJ 2014;348:g1687.

\section{Hwang 2009}

Hwang R, Marwick T. Efficacy of home-based exercise programmes for people with chronic heart failure: a metaanalysis. European Journal of Cardiovascular Prevention and Rehabilitation 2009;16:527-35.

\section{Jolliffe 2001}

Jolliffe JA, Rees K, Taylor RS, Thompson D, Oldridge N, Ebrahim S. Exercise-based rehabilitation for coronary heart disease. Cochrane Database of Systematic Reviews 2001, Issue 1. Art. No: CD001800. [DOI: 10.1002/14651858.CD001800]

\section{Jolly 1998}

Jolly K, Bradley F, Sharp S, Smith H, Mant D. Follow-up care in general practice of patients with myocardial infarction or angina pectoris: initial results of the SHIP trial. Southampton Heart Integrated Care Project. Family Practice 1998;15:548-55.

\section{Jolly 2007}

Jolly K, Taylor R, Lip GY, Greenfield S, Raftery J, Mant J, et al. The Birmingham Rehabilitation Uptake Maximisation Study (BRUM). Home-based compared with hospital-based cardiac rehabilitation in a multi-ethnic population: costeffectiveness and patient adherence. Health Technology Assessment 2007;11:1-118.

\section{Koongstvedt 2001}

Koongstvedt PR. The Managed Health Care Handbook. 4th edition. New York: Aspen Publishers, 2001.

\section{Kostis 1997}

Kostis JB, Davis BR, Cutler J, Grimm RH Jr, Berge KG, Cohen JD, et al. Prevention of heart failure by antihypertensive drug treatment in older persons with isolated systolic hypertension. SHEP Cooperative Research Group. JAMA 1997;278:212-6.

\section{Kung 2010}

Kung J, Chiappelli F, Cajulis OO, Avezova R, Kossan G, Chew L, et al. From systematic reviews to clinical recommendations for evidence-based health care: validation of Revised Assessment of Multiple Systematic Reviews (R-AMSTAR) for grading of clinical relevance. Open Dentistry Journal 2010;4:84-91.

\section{Lawler 2011}

Lawler PR, Filion KB, Eisenberg MJ. Efficacy of exercise-based cardiac rehabilitation post-myocardial infarction: a systematic review and meta-analysis of randomized controlled trials. American Heart Journal 2011;162:571-84.

\section{Lisspers 1999}

Lisspers J, Sundin O, Hofman-Bang C, Nordlander R, Nygren A, Ryden $\mathrm{L}$, et al. Behavioral effects of a comprehensive, multifactorial program for lifestyle change after percutaneous transluminal coronary angioplasty: a prospective, randomized controlled study. Journal of Psychosomatic Research 1999;46:143-54.

\section{Mathers 2008}

Mathers C, Fat D, Boerma JT. The global burden of disease: 2004 update. World Health Organization, 2008.

\section{McKelvie 2013}

McKelvie R S, Moe G W, Ezekowitz J A, Heckman G A, Costigan J, Ducharme A, et al. The 2012 Canadian Cardiovascular Society heart failure management guidelines update: focus on acute and chronic heart failure. Can J Cardiol 2013;29:168-81.

\section{McMurray 2005}

McMurray JJ, Pfeffer MA. Heart failure. Lancet 2005;365:1877-89. 


\section{McMurray 2012}

McMurray John JV, Adamopoulos Stamatis, Anker Stefan D, Auricchio Angelo, Böhm Michael, Dickstein Kenneth, et al. ESC Guidelines for the diagnosis and treatment of acute and chronic heart failure 2012 The Task Force for the Diagnosis and Treatment of Acute and Chronic Heart Failure 2012 of the European Society of Cardiology. Developed in collaboration with the Heart Failure Association (HFA) of the ESC. European heart journal 2012;33:1787-847.

\section{Mechta-Nielsen 2014}

Mechta-Nielsen. Exercise-based cardiac rehabilitation for adult patients with ICD [personal communication]. Email to: L Anderson 9 May 2014.

\section{Mehta 2009}

Mehta PA, Dubrey SW, McIntyre HF, Walker DM, Hardman SM, Sutton GC, et al. Improving survival in the 6 months after diagnosis of heart failure in the past decade: population-based data from the UK. Heart 2009;95:1851-6.

\section{Miller 1984}

Miller NH, Haskell WL, Berra K, DeBusk RF. Home versus group exercise training for increasing functional capacity after myocardial infarction. Circulation 1984;70:645-9.

\section{Mills 2013}

Mills EJ, Thorlund K, loannidis JP. Demystifying trial networks and network meta-analysis. BMJ 2013;346:f2914.

\section{Moore 2003}

Moore SM, Dolansky MA, Ruland CM, Pashkow FJ, Blackburn GG. Predictors of women's exercise maintenance after cardiac rehabilitation. Journal of Cardiopulmonary Rehabilitation 2003;23:40-9.

\section{NICE 2013}

NICE. Clinical guideline 172. MI - secondary prevention. Secondary prevention in primary and secondary care for patients following a myocardial infarction. www.nice.org.uk/ guidance/cg172 2013.

\section{NICE 2013b}

NICE. Commissioning guides 40. Cardiac rehabilitation services. www.nice.org.uk/guidance/cmg40 2013.

\section{O'Connor 1989}

O'Connor GT, Buring JE, Yusuf S, Goldhaber SZ, Olmstead EM, Paffenbarger RS Jr, et al. An overview of randomized trials of rehabilitation with exercise after myocardial infarction. Circulation 1989;80:234-44.

\section{Oldridge 1988}

Oldridge NB, Guyatt GH, Fischer ME, Rimm AA. Cardiac rehabilitation after myocardial infarction. Combined experience of randomized clinical trials. JAMA 1988;260:945-50.

\section{Oldridge 2012}

Oldridge N. Exercise-based cardiac rehabilitation in patients with coronary heart disease: meta-analysis outcomes revisited. Future of Cardiology 2012;8:729-51.

\section{Perk 2012}

Perk J, De Backer G, Gohlke H, Graham I, Reiner Z, Verschuren M, et al. European Guidelines on cardiovascular disease prevention in clinical practice (version 2012). The Fifth Joint Task Force of the European Society of Cardiology and Other Societies on Cardiovascular Disease Prevention in Clinical Practice (constituted by representatives of nine societies and by invited experts). European Heart Journal 2012;33(13):1635-701.

\section{Petticrew 2013}

Petticrew M, Anderson L, Elder R, Grimshaw J, Hopkins D, Hahn R, et al. Complex interventions and their implications for systematic reviews: a pragmatic approach. Journal of Clinical Epidemiology 2013;66:1209-14.

\section{Piepoli 2004}

Piepoli MF, Davos C, Francis DP, Coats AJ, ExTra Match Collaborative. Exercise training meta-analysis of trials in patients with chronic heart failure (ExTraMATCH). BMJ 2004;328:189.

\section{PRECOR 1991}

PRECOR, Leizoroviez A, Saint-Pierre A, Vasselon C, Boissel JP. Comparison of a rehabilitation programme, a counselling programme and usual care after an acute myocardial infarction: results of a long-term randomized trial. European Heart Journal 1991;12:612-6.

\section{Racca 2010}

Racca V, Spezzaferri R, Modica M, Mazzini P, Jonsdottir J, De Maria R, et al. Functioning and disability in ischaemic heart disease. Disability and Rehabilitation 2010;32 Suppl 1:S42-9.

\section{RevMan 2014 [Computer program]}

The Nordic Cochrane Centre, The Cochrane Collaboration Review Manager (RevMan). Version 5.3. Copenhagen: The Nordic Cochrane Centre, The Cochrane Collaboration, 2014.

\section{Risom 2014}

Risom SS, Zwisler A-D, Johansen PP, Sibilitz KL, Lindschou J, Taylor RS, et al. Exercise-based cardiac rehabilitation for adults with atrial fibrillation. Cochrane Database of Systematic Reviews 2014, Issue 7. Art. No: CD011197. [DOI: 10.1002/14651858.CD011197]

\section{Shea 2009}

Shea BJ, Hamel C, Wells GA, Bouter LM, Kristjansson E, Grimshaw J, et al. AMSTAR is a reliable and valid measurement tool to assess the methodological quality of systematic reviews. Journal of Clinical Epidemiology 2009;62:1013-20.

\section{Sibilitz 2013}

Sibilitz KL, Berg SK, Tang LH, Risom SS, Gluud C, Lindschou J, et al. Exercise-based cardiac rehabilitation for adults after heart valve surgery. Cochrane Database of Systematic Reviews 2013, Issue 12. Art. No: CD010876. [DOI: 10.1002/14651858.CD010876]

\section{Stern 1983}

Stern MJ, Gorman PA, Kaslow L. The group counselling v exercise therapy study. A controlled intervention with subjects 
following myocardial infarction. Archives of Internal Medicine 1983;143:1719-25.

\section{Task Force Members 2013}

Task Force Members, Montalescot G, Sechtem U, Andreotti F, Arden C, Budaj A, et al. 2013 ESC guidelines on the management of stable coronary artery disease: the Task Force on the management of stable coronary artery disease of the European Society of Cardiology. European Heart Journal 2013;34(38):2949-3003.

\section{Taylor 2004}

Taylor RS, Brown A, Ebrahim S, Jolliffe J, Noorani H, Rees K, et al. Exercise-based rehabilitation for patients with coronary heart disease: systematic review and meta-analysis of randomized controlled trials. American Journal of Medicine 2004;116:682-92.

\section{Taylor 2006}

Taylor RS, Unal B, Critchley JA, Capewell S. Mortality reductions in patients receiving exercise-based cardiac rehabilitation: how much can be attributed to cardiovascular risk factor improvements? European Journal of Cardiovascular Prevention and Rehabilitation 2006;13:369-74.

\section{Taylor 2012}

Taylor RS, Cochrane Review Authors. The RAMIT trial: its results in the context of 2012 Cochrane review. Heart 2012;98:672-3.

\section{Tierney 2011}

Tierney S, Mamas M, Skelton D, Woods S, Rutter MK, Gibson M, et al. What can we learn from patients with heart failure about exercise adherence? A systematic review of qualitative papers. Health Psychology 2011;30:401-10.

\section{Weir 2012}

Weir MC, Grimshaw, JM, Mayhew A, Fergusson D. Decisions about lumping vs. splitting of the scope of systematic reviews of complex interventions are not well justified: a case study in systematic reviews of health care professional reminders. Journal of Clinical Epidemiology 2012;65:756-63.

\section{West 2012}

West RR, Jones DA, Henderson AH. Rehabilitation After Myocardial Infarction Trial (RAMIT): multi-centre randomised controlled trial of comprehensive cardiac rehabilitation in patients following acute myocardial infarction. Heart 2012;98:637-44.

\section{WHO 2014}

World Health Organization (WHO). Global health observatory data repository. apps.who.int/gho/data/node.main (accessed 7 December 2014).

\section{Yancy 2013}

Yancy CW, Jessup M, Bozkurt B, Butler J, Casey DE, Drazner MH, et al. 2013 ACCF/AHA Guideline for the Management of Heart Failure. A report of the American College of Cardiology Foundation/American Heart Association Task Force on Practice Guidelines. Journal of the American College of Cardiology 2013;62:e147-239.

\section{ADDITIONAL TABLES}

Table 1. Summary of included Cochrane review characteristics

\begin{tabular}{|c|c|c|c|c|c|c|}
\hline $\begin{array}{l}\text { Review } \\
\text { short title } \\
\text { (reference) }\end{array}$ & $\begin{array}{l}\text { Exercise for CHD } \\
\text { (Heran 2011) }\end{array}$ & $\begin{array}{l}\text { Exercise } \\
\text { for HF } \\
\text { (Taylor } \\
2014 b \text { ) }\end{array}$ & $\begin{array}{l}\text { Psychological } \\
\text { for CHD } \\
\text { (Whalley 2011) }\end{array}$ & $\begin{array}{l}\text { Education for } \\
\text { CHD } \\
\text { (Brown 2011) }\end{array}$ & $\begin{array}{l}\text { Home vs. centre } \\
\text { (Taylor 2014a) }\end{array}$ & $\begin{array}{l}\begin{array}{l}\text { Uptake and } \\
\text { adherence }\end{array} \\
\text { (Karmali 2014) }\end{array}$ \\
\hline $\begin{array}{l}\text { Main ob- } \\
\text { jective }\end{array}$ & $\begin{array}{l}\text { To determine the } \\
\text { effectiveness of ex- } \\
\text { ercise-based CR } \\
\text { (exercise training } \\
\text { alone or in com- } \\
\text { bination with psy- } \\
\text { chosocial or edu- } \\
\text { cational interven- } \\
\text { tions) on mortali- } \\
\text { ty, morbidity and } \\
\text { HRQoL of people } \\
\text { with CHD }\end{array}$ & $\begin{array}{l}\text { To de- } \\
\text { termine } \\
\text { the effec- } \\
\text { tiveness } \\
\text { of exer- } \\
\text { cise-based } \\
\text { interven- } \\
\text { tions com- } \\
\text { pared with } \\
\text { usual med- } \\
\text { ical care by } \\
\text { focusing } \\
\text { on mortali- } \\
\text { ty, hospital } \\
\text { admission } \\
\text { rate, mor- } \\
\text { bidity and } \\
\text { HRQoL in }\end{array}$ & $\begin{array}{l}\text { To determine the } \\
\text { independent ef- } \\
\text { fects of psycho- } \\
\text { logical interven- } \\
\text { tions in people } \\
\text { with CHD }\end{array}$ & $\begin{array}{l}\text { To assess the } \\
\text { effects of pa- } \\
\text { tient educa- } \\
\text { tion on mor- } \\
\text { tality, mor- } \\
\text { bidity, HRQoL } \\
\text { and healthcare } \\
\text { costs in people } \\
\text { with CHD }\end{array}$ & $\begin{array}{l}\text { To determine the ef- } \\
\text { fectiveness of home- } \\
\text { based CR programmes } \\
\text { compared with super- } \\
\text { vised centre-based } \\
\text { CR on mortality and } \\
\text { morbidity, HRQoL and } \\
\text { modifiable cardiac risk } \\
\text { factors in people with } \\
\text { CHD }\end{array}$ & $\begin{array}{l}\text { To determine } \\
\text { the harms and } \\
\text { benefits of in- } \\
\text { terventions to } \\
\text { increase pa- } \\
\text { tient uptake } \\
\text { of, and adher- } \\
\text { ence to, CR }\end{array}$ \\
\hline
\end{tabular}


Table 1. Summary of included Cochrane review characteristics (Continued) people with

HF

\begin{tabular}{|c|c|c|c|c|}
\hline $\begin{array}{l}\text { Search } \\
\text { time frame }\end{array}$ & $\begin{array}{l}\text { November } 2000 \text { to } \\
\text { December } 2009\end{array}$ & $\begin{array}{l}2008 \text { to } \\
\text { March } 2013\end{array}$ & $\begin{array}{l}2001 \text { to January } \\
2009\end{array}$ & $\begin{array}{l}1990 \text { to August } \\
2010\end{array}$ \\
\hline $\begin{array}{l}\text { Study de- } \\
\text { sign }\end{array}$ & $\begin{array}{l}\text { RCTs (follow-up } \geq 6 \\
\text { months) }\end{array}$ & $\begin{array}{l}\text { RCTs (fol- } \\
\text { low-up } \geq 6 \\
\text { months) }\end{array}$ & $\begin{array}{l}\text { RCTs (no mini- } \\
\text { mum follow-up) }\end{array}$ & $\begin{array}{l}\text { RCTs (follow-up } \\
\geq 6 \text { months) }\end{array}$ \\
\hline \multirow[t]{9}{*}{ Population } & Inclusion & Inclusion & Inclusion & Inclusion \\
\hline & Post-MI & $\mathrm{HF}$ & Post-MI & Post-MI \\
\hline & $\begin{array}{l}\text { Post revascularisa- } \\
\text { tion }\end{array}$ & $\begin{array}{l}\text { Exclusion } \\
\text { Previous CR }\end{array}$ & $\begin{array}{l}\text { Post revasculari- } \\
\text { sation }\end{array}$ & $\begin{array}{l}\text { Post revascular- } \\
\text { isation }\end{array}$ \\
\hline & CHD defined by an- & & Angina & Angina \\
\hline & Exclusion & & $\begin{array}{l}\text { CHD defined by } \\
\text { angiography }\end{array}$ & $\begin{array}{l}\text { CHD defined by } \\
\text { angiography }\end{array}$ \\
\hline & Heart valve surgery & & Exclusion & \\
\hline & $\mathrm{HF}$ & & None & \\
\hline & $\begin{array}{l}\text { Heart transplanta- } \\
\text { tion }\end{array}$ & & & \\
\hline & CRT or ICD implant & & & \\
\hline
\end{tabular}

$\begin{array}{ll}2008 \text { to November } & 2008 \text { to Janu- } \\ 2012 & \text { ary } 2013\end{array}$

RCTs (no minimum fol- RCTs (no minlow-up) imum follow-up)

Inclusion

Post-MI

Post-MI

Post revascularisation

Post revascu-

Angina

HF

Exclusion larisation

Angina

HF

Heart transplantation

CRT or CD implant

Previous CR

CHD

Exclusion

Heart transplantation

CRT or ICD implant

\begin{tabular}{ll}
\hline Interven- & Exercise training \\
tion & with or without the \\
& addition of psy- \\
& chosocial or educa- \\
& tional interventions \\
& (or both)
\end{tabular}

\section{Exercise} training with or without the addition of psychosocial or educational interventions (or both)
Psychological interventions delivered by healthcare workers with specific training in psychological techniques
Patient education interventions involving direct contact with a health professional and including structured knowledge transfer about CHD
CR programmes delivered in a home-based setting
CR plus any intervention with the specific aim of increasing patient uptake of, or adherence to, CR or any of its component parts

\begin{tabular}{|c|c|c|c|c|c|c|}
\hline $\begin{array}{l}\text { Compara- } \\
\text { tor }\end{array}$ & $\begin{array}{l}\text { No exercise training } \\
\text { control that could } \\
\text { include psychologi- } \\
\text { cal, educational in- } \\
\text { terventions, stan- } \\
\text { dard medical care } \\
\text { or a combination }\end{array}$ & $\begin{array}{l}\text { No exercise } \\
\text { training } \\
\text { control that } \\
\text { could in- } \\
\text { clude psy- } \\
\text { chological, } \\
\text { education- } \\
\text { al interven- } \\
\text { tions, stan- } \\
\text { dard med- } \\
\text { ical care or } \\
\text { a combina- } \\
\text { tion }\end{array}$ & $\begin{array}{l}\text { No psychological } \\
\text { intervention con- } \\
\text { trol that could } \\
\text { include exercise } \\
\text { interventions or } \\
\text { standard med- } \\
\text { ical care }\end{array}$ & $\begin{array}{l}\text { No education } \\
\text { intervention } \\
\text { control that } \\
\text { could include } \\
\text { exercise inter- } \\
\text { ventions or } \\
\text { standard med- } \\
\text { ical care }\end{array}$ & $\begin{array}{l}\text { CR programmes deliv- } \\
\text { ered in a centre-based } \\
\text { setting }\end{array}$ & $\begin{array}{l}\text { CR pro- } \\
\text { grammes } \\
\text { without the } \\
\text { intervention }\end{array}$ \\
\hline Outcomes & $\begin{array}{l}\text { - Mortality (total, } \\
\text { CV, non-CV) } \\
\text { - MI (total, fatal, } \\
\text { non-fatal) }\end{array}$ & $\begin{array}{l}\text { Mortali- } \\
\text { ty (to- } \\
\text { tal, HF } \\
\text { and sud- }\end{array}$ & $\begin{array}{l}\text { - Mortality (to- } \\
\text { tal and CV) } \\
\text { - Morbidity } \\
\text { (non-fatal MI) }\end{array}$ & $\begin{array}{l}\text { - Mortality (to- } \\
\text { tal, CV and } \\
\text { non-CV) }\end{array}$ & $\begin{array}{l}\text { - Mortality (total and } \\
\text { CV) } \\
\text { - Morbidity (reinfarc- } \\
\text { tion, revascularisa- }\end{array}$ & $\begin{array}{l}\text { Uptake of, or } \\
\text { adherence to, } \\
\text { CR (primary) }\end{array}$ \\
\hline
\end{tabular}


Table 1. Summary of included Cochrane review characteristics (Continued)

- Revascularisa-

$\begin{array}{lll}\text { den } & \cdot & \text { Revasculari- } \\ \text { death) } & \text { sation (CABG } \\ \text { Hospi- } & \text { and PTCA) } \\ \text { talisa- } & \text { - } \begin{array}{l}\text { Psychological } \\ \text { tion (to- }\end{array} & \text { well-being } \\ \text { tal, HF) } & \text { anxiety, de- } \\ \text { HRQoL } & \text { pression, } \\ \text { Eco- } & \text { stress and } \\ \text { nomic } & \text { Type A } \\ \text { (costs } & \text { Behav- } \\ \text { and } & \text { iour/hostility } \\ \text { cost- } & \text { HRQoL } \\ \text { effec- } & \\ \text { tive- } & \\ \text { ness) } & \end{array}$

Total

tions (tot

events

CV

CABG, PTCA, restenting)

- MI (fatal or non-fatal, or

- Hospitalisations (total, CV, other) both)

- HRQoL

Other fatal

- Economic (costs and cost-effectiveness) or non-fatal (or both) CV events

- Revascularisations (CABG, PTCA with or without stenting)

- Hospitalisations (cardiac-related)

- HRQoL

- Withdrawals/dropouts

tion, cardiac-associated hospitalisation)

- Exercise capacity

- Risk factors (smoking behaviour, blood lipid levels, blood pressure)

- HRQoL

- Adverse events (withdrawal from the exercise programme)

- Adherence to rehabilitation

- Economic (health service use, costs and cost-effectiveness)

- Economic (healthcare costs and costeffectiveness)

\begin{tabular}{|c|c|c|c|c|c|c|}
\hline $\begin{array}{l}\text { Funding } \\
\text { source }\end{array}$ & $\begin{array}{l}\text { NIHR, UK Cochrane } \\
\text { Collaboration Pro- } \\
\text { gramme Grant, UK }\end{array}$ & $\begin{array}{l}\text { None spec- } \\
\text { ified }\end{array}$ & $\begin{array}{l}\text { Department of } \\
\text { Social Medicine, } \\
\text { University of } \\
\text { Bristol, UK } \\
\text { Health Services } \\
\text { Research Fo- } \\
\text { cus, University of } \\
\text { Wales College of } \\
\text { Medicine, UK } \\
\text { British Heart } \\
\text { Foundation, UK } \\
\text { ESCR, UK } \\
\text { NIHR, UK } \\
\text { Cochrane Col- } \\
\text { laboration Heart } \\
\text { Programme } \\
\text { Grant, UK }\end{array}$ & $\begin{array}{l}\text { NIHR, UK } \\
\text { Cochrane Col- } \\
\text { laboration Pro- } \\
\text { gramme Grant, } \\
\text { UK }\end{array}$ & $\begin{array}{l}\text { NIHR Cochrane Heart } \\
\text { Programme grant, UK } \\
\text { Transparency of } \\
\text { the National Health } \\
\text { System Drug Reim- } \\
\text { bursement Decisions, } \\
\text { Poland, EU }\end{array}$ & $\begin{array}{l}\text { NIHR pro- } \\
\text { gramme } \\
\text { grant, UK }\end{array}$ \\
\hline $\begin{array}{l}\text { Authors' } \\
\text { declara- } \\
\text { tions of in- } \\
\text { terest }\end{array}$ & $\begin{array}{l}\text { Authors were au- } \\
\text { thors of the original } \\
\text { Cochrane review. } \\
\text { RST was a co-inves- } \\
\text { tigator on a number } \\
\text { of CR RCTs }\end{array}$ & - & None declared & None declared & $\begin{array}{l}\text { RST was a co-author of } \\
\text { the original Cochrane } \\
\text { review and was a co- } \\
\text { investigator on a num- } \\
\text { ber of CR RCTs }\end{array}$ & None declared \\
\hline
\end{tabular}

CABG: coronary artery bypass graft; CAD: coronary artery disease; CHD: coronary heart disease; CR: cardiac rehabilitation; CRT: cardiac resynchronisation therapy; CV: cardiovascular; ESCR: Economic and Social Research Council; HF: heart failure; HRQoL: health-related 
quality of life; ICD: implantable cardioverter defibrillator; MI: myocardial infarction; NIHR: National Institute of Health Research; PTCA: percutaneous transluminal coronary angioplasty; RCT: randomised controlled trial.

Table 2. Summary of characteristics of included RCTs

\begin{tabular}{|c|c|c|c|c|c|c|}
\hline $\begin{array}{l}\text { Review short title } \\
\text { (reference) }\end{array}$ & $\begin{array}{l}\text { Exercise } \\
\text { for CHD } \\
\text { (Heran } \\
2011)\end{array}$ & $\begin{array}{l}\text { Exercise for } \\
\text { HF } \\
\text { (Taylor } \\
\text { 2014b) }\end{array}$ & $\begin{array}{l}\text { Psycho- } \\
\text { logical for } \\
\text { CHD } \\
\text { (Whalley } \\
2011 \text { ) }\end{array}$ & $\begin{array}{l}\text { Education } \\
\text { for CHD } \\
\text { (Brown 2011) }\end{array}$ & $\begin{array}{l}\text { Home vs. } \\
\text { centre } \\
\text { (Taylor } \\
2014 a)\end{array}$ & $\begin{array}{l}\text { Uptake and adherence } \\
\text { (Karmali 2014) }\end{array}$ \\
\hline
\end{tabular}

\section{RCTs (participants)}

\begin{tabular}{lllllll}
\hline Number & 47 RCTs & 33 RCTs & 24 RCTs & 13 RCTs & 17 RCTs & 18 RCTs \\
& $(10,794)$ & $(4740)$ & $(9296)$ & $(68,556)$ & $(2172)$ & $(2505)$
\end{tabular}

\begin{tabular}{|c|c|c|c|c|c|c|}
\hline \multicolumn{7}{|c|}{ Nature of intervention ${ }^{\star}$} \\
\hline Exercise only & 17 & 21 & 0 & 0 & 6 & \multirow{2}{*}{$\begin{array}{l}\text { Interventions aimed at } \\
\text { increasing patient up- } \\
\text { take of CR (10 RCTs) }\end{array}$} \\
\hline Psychological only & 0 & 0 & 14 & 0 & 0 & \\
\hline Education only & 0 & 0 & 0 & 13 & 0 & $\begin{array}{l}\text { Interventions designed } \\
\text { to increase adherence }\end{array}$ \\
\hline$>1$ intervention & $29^{\star}$ & 12 & $\begin{array}{l}10 \text { (psycho- } \\
\text { logical and } \\
\text { education) }\end{array}$ & 0 & 11 & supervised CR (1 RCT) \\
\hline
\end{tabular}

\begin{tabular}{lllllll}
\hline Sample size & 142 & 54 & 133 & 288 & 104 & 110 \\
\hline Median (range) & $(28$ to 2304) & $($ (19 to 2331) & $(44$ to 2481) & $\begin{array}{l}(87 \text { to } \\
46,606)\end{array}$ & (20 to 525) & (16 to 597)
\end{tabular}

\section{Intervention duration [months]}

\begin{tabular}{llllllll}
\hline Median (range) months & $3(1$ to 30$)$ & $6(1$ to 120$)$ & NR & $6(1$ to 30$)$ & $3(1.5$ to 6$)$ & NR & \\
\hline
\end{tabular}

\section{Publication year (number of RCTs)}

\begin{tabular}{|c|c|c|c|c|c|c|}
\hline 1970-1979 & 2 & 0 & 2 & 0 & 0 & 0 \\
\hline 1990-1999 & 11 & 0 & 4 & 0 & 1 & 2 \\
\hline 1990-1999 & 20 & 5 & 8 & 4 & 2 & 3 \\
\hline 2000-2009 & 14 & 20 & 10 & 9 & 11 & 8 \\
\hline $2010+$ & 0 & 8 & 0 & 0 & 3 & 5 \\
\hline \multicolumn{7}{|l|}{$\%$ male } \\
\hline Median (range) & $\begin{array}{l}88(0 \text { to } \\
100)\end{array}$ & $\begin{array}{l}80 \text { (36 to } \\
100)\end{array}$ & $\begin{array}{l}84(0 \text { to } \\
100)\end{array}$ & 60 (0 to 100$)$ & $\begin{array}{l}80 \text { (60 to } \\
100)\end{array}$ & 84 (0 to 100$)$ \\
\hline
\end{tabular}


Table 2. Summary of characteristics of included RCTs (Continued)

\section{$\%$ white}

\begin{tabular}{|c|c|c|c|c|c|c|}
\hline Median (range) & NR & $\begin{array}{l}85 \text { (60 to } \\
100) \text { from } 8 \\
\text { RCTs }\end{array}$ & NR & $\begin{array}{l}86 \text { (55 to } 97) \\
\text { from } 6 \text { RCTs }\end{array}$ & $\begin{array}{l}80 \text { from } 1 \\
\text { RCT }\end{array}$ & $\begin{array}{l}79 \text { ( } 43 \text { to } 95 \text { ) from } 6 \\
\text { RCTs }\end{array}$ \\
\hline
\end{tabular}

\section{Age (years)}

\begin{tabular}{|c|c|c|c|c|c|}
\hline Median (range) & $\begin{array}{l}55 \text { ( } 49 \text { to } \\
70)\end{array}$ & $60(51$ to 81$)$ & $\begin{array}{l}57 \text { (51 to } \\
62)\end{array}$ & 62 (51 to 73 ) & $\begin{array}{l}60 \text { ( } 52 \text { to } \\
69)\end{array}$ \\
\hline
\end{tabular}

\section{Indication (number of RCTs)}

\begin{tabular}{lllllll}
\hline Ml only & 28 & 0 & 10 & 2 & 4 & 0 \\
\hline Angina only & 1 & 0 & 1 & 1 & 2 & 0 \\
\hline Revascularisation only & 1 & 0 & 4 & 1 & 5 & 3 \\
\hline $\begin{array}{l}\text { Ml or revascularisation (or } \\
\text { both) }\end{array}$ & 4 & 0 & 4 & 0 & 0 & 7 \\
\hline Ml or angina & 4 & 0 & 2 & 4 & 0 & 1 \\
\hline Mixed CHD & 9 & 0 & 2 & 3 CHD or HF & 3 \\
\hline HF & 0 & 33 & 0 & 0 & 1
\end{tabular}

\section{Study location (number of RCTs (\%))}

\begin{tabular}{lllllll}
\hline Europe & $20(43)$ & $20(64)$ & $11(46)$ & $7(54)$ & $10(58)$ & $6(33)$ \\
\hline North America & $3(6)$ & $11(30)$ & $11(46)$ & $6(46)$ & $5(29)$ & $11(61)$ \\
\hline Asia/Australia & $7(15)$ & $1(3)$ & $2(8)$ & 0 & $1(6)$ & $1(6)$ \\
\hline Other & - & $1(3)$ & 0 & 0 & 0 & 0 \\
\hline NR & $17(36)$ & 0 & 0 & 0 & 0 \\
\hline
\end{tabular}

\section{Single centre}

\begin{tabular}{lllllll}
\hline Number of RCTs $(\%)$ & $23(49)$ & $30(91)$ & $8(33)$ & $4(31)$ & $15(88)$ & $10 / 16(63)^{\star \star}$
\end{tabular}

\section{Follow-up duration [months]}

\begin{tabular}{lllllll}
\hline Median (range) & $\begin{array}{l}24(6 \text { to } \\
120)\end{array}$ & $6(6$ to 120$)$ & NR & $18(6$ to 60$)$ & $6(2$ to 72$)$ & $3(1.5$ to 12$)$ \\
\hline
\end{tabular}

CHD: coronary heart disease; HF: heart failure; MI: myocardial infarction; NR: not reported; RCT: randomised controlled trial.

* 1 RCT randomly assigned to exercise-only or comprehensive intervention.

${ }^{\star \star} 2$ studies were unavailable to us as they were unpublished degree dissertations. 
Table 3. R-AMSTAR assessment of included systematic reviews

\begin{tabular}{|c|c|c|c|c|c|c|}
\hline $\begin{array}{l}\text { Review short title } \\
\text { (reference) }\end{array}$ & $\begin{array}{l}\text { Exercise } \\
\text { for CHD } \\
\text { (Heran } \\
2011)\end{array}$ & $\begin{array}{l}\text { Exercise } \\
\text { for HF } \\
\text { (Taylor } \\
\text { 2014b) }\end{array}$ & $\begin{array}{l}\text { Psycho- } \\
\text { logical for } \\
\text { CHD } \\
\text { (Whalley } \\
\text { 2011) }\end{array}$ & $\begin{array}{l}\begin{array}{l}\text { Education } \\
\text { for CHD }\end{array} \\
\text { (Brown } \\
2011 \text { ) }\end{array}$ & $\begin{array}{l}\text { Home vs. } \\
\text { centre } \\
\text { (Taylor } \\
2014 a \text { ) }\end{array}$ & $\begin{array}{l}\text { Uptake } \\
\text { and adher- } \\
\text { ence } \\
\text { (Karmali } \\
2014 \text { ) }\end{array}$ \\
\hline
\end{tabular}

\section{Was an 'a priori' design provided?}

\begin{tabular}{|c|c|c|c|c|c|c|}
\hline (A) 'a priori' design & Yes & Yes & Yes & Yes & Yes & Yes \\
\hline (B) Statement of inclusion criteria & Yes & Yes & Yes & Yes & Yes & Yes \\
\hline $\begin{array}{l}\text { (C) PICO/PIPO research question (popula- } \\
\text { tion, intervention, comparison, prediction, } \\
\text { outcome) }\end{array}$ & Yes & Yes & Yes & Yes & Yes & Yes \\
\hline Score & 4 & 4 & 4 & 4 & 4 & 4 \\
\hline
\end{tabular}

\section{Was there duplicate study selection and data extraction?}

\begin{tabular}{lllllll}
$\begin{array}{l}\text { (A) There should be at least } 2 \text { independent } \\
\text { data extractors as stated or implied }\end{array}$ & Yes & *Yes & *Yes & *Yes & *Yes & Yes \\
\hline $\begin{array}{l}\text { (B) Statement of recognition or awareness } \\
\text { of consensus procedure for disagreements }\end{array}$ & Yes & Yes & Yes & Yes & Yes & Yes \\
\hline $\begin{array}{l}\text { (C) Disagreements among extractors re- } \\
\text { solved properly as stated or implied }\end{array}$ & Yes & Yes & Yes & Yes & Yes & Yes \\
\hline Score & 4 & 4 & 4 & 4 & 4 & Yes \\
\hline
\end{tabular}

\section{Was a comprehensive literature search performed?}

\begin{tabular}{|c|c|c|c|c|c|c|}
\hline $\begin{array}{l}\text { (A) At least } 2 \text { electronic sources should be } \\
\text { searched }\end{array}$ & Yes & Yes & Yes & Yes & Yes & Yes \\
\hline
\end{tabular}

\begin{tabular}{|c|c|c|c|c|c|c|}
\hline $\begin{array}{l}\text { (D) In addition to the electronic databases } \\
\text { (PubMed, MEDLINE, EMBASE), all search- } \\
\text { es should be supplemented by consulting } \\
\text { current contents, reviews, textbooks, spe- } \\
\text { cialised registers, or experts in the particu- } \\
\text { lar field of study, and by reviewing the ref- } \\
\text { erences in the studies found }\end{array}$ & No & Yes & Yes & Yes & Yes & No \\
\hline $\begin{array}{l}\text { (E) Journals were "hand-searched" or } \\
\text { "manual searched" (i.e. identifying highly } \\
\text { relevant journals and conducting a manu- }\end{array}$ & No & No & No & No & No & No \\
\hline
\end{tabular}


Table 3. R-AMSTAR assessment of included systematic reviews (Continued)

al, page-by-page search of their entire con-

tents looking for potentially eligible stud-

ies)

\begin{tabular}{lllllll}
\hline Score & 3 & 4 & 4 & 4 & 4 & 3 \\
\hline
\end{tabular}

4. Was the status of publication (i.e. grey literature) used as an inclusion criterion?

$\begin{aligned} & \text { (A) The authors should state that they } \\ & \text { searched for reports regardless of their }\end{aligned}$
publication type

$\begin{array}{lllllll}\text { (B) The authors should state whether or } & \text { Yes } & \text { Yes } & \text { Yes } & \text { Yes } & \text { Yes }\end{array}$

not they excluded any reports (from the systematic review), based on their publication status, language, etc.

\begin{tabular}{lcccccc}
$\begin{array}{l}\text { (C) "Non-English papers were translated" } \\
\text { or readers sufficiently trained in foreign } \\
\text { language }\end{array}$ & Yes & No & Yes & Yes & No & No \\
\hline $\begin{array}{l}\text { (D) No language restriction or recognition } \\
\text { of non-English articles }\end{array}$ & Yes & Yes & Yes & Yes & Yes & Yes \\
\hline Score & 4 & 3 & 4 & 4 & 4 & 3 \\
\hline
\end{tabular}

\section{Was a list of studies (included and excluded) provided?}

\begin{tabular}{|c|c|c|c|c|c|c|}
\hline $\begin{array}{l}\text { (A) Table/list/figure of included studies, a } \\
\text { reference list does not suffice }\end{array}$ & Yes & Yes & Yes & Yes & Yes & Yes \\
\hline
\end{tabular}

\begin{tabular}{|c|c|c|c|c|c|c|}
\hline $\begin{array}{l}\text { (C) Author satisfactorily/sufficiently stated } \\
\text { the reason for exclusion of the seriously } \\
\text { considered studies }\end{array}$ & Yes & Yes & Yes & Yes & Yes & Yes \\
\hline
\end{tabular}

\begin{tabular}{lllll}
$\begin{array}{l}\text { (D) Reader was able to retrace the includ- } \\
\text { ed and the excluded studies anywhere in } \\
\text { the article bibliography, reference or sup- } \\
\text { plemental source }\end{array}$ & Yes & Yes & Yes \\
\hline Score & 4 & 4 & 4 & 4 \\
\hline
\end{tabular}

\section{Were the characteristics of the included studies provided?}

\begin{tabular}{|c|c|c|c|c|c|c|}
\hline $\begin{array}{l}\text { (A) In an aggregated form such as a table, } \\
\text { data from the original studies should be } \\
\text { provided on the participants, interventions } \\
\text { AND outcomes }\end{array}$ & Yes & Yes & Yes & Yes & Yes & Yes \\
\hline $\begin{array}{l}\text { (B) Provide the ranges of relevant charac- } \\
\text { teristics in the studies analysed (e.g. age, } \\
\text { race, sex, relevant socioeconomic data, }\end{array}$ & Yes & Yes & Yes & Yes & Yes & Yes \\
\hline
\end{tabular}


Table 3. R-AMSTAR assessment of included systematic reviews (Continued)

disease status, duration, severity or other diseases should be reported)

\begin{tabular}{|c|c|c|c|c|c|c|}
\hline $\begin{array}{l}\text { (C) The information provided appears to } \\
\text { be complete and accurate (i.e. there was a } \\
\text { tolerable range of subjectivity here. Is the } \\
\text { reader left wondering? If so, state the need- } \\
\text { ed information and the reasoning) }\end{array}$ & Yes & Yes & Yes & Yes & Yes & Yes \\
\hline Score & 4 & 4 & 4 & 4 & 4 & 4 \\
\hline
\end{tabular}

\section{Was the scientific quality of the included studies assessed and documented?}

$\begin{aligned} & \text { (A) 'A priori' methods of assessment should } \\ & \text { be provided (e.g. for effectiveness studies }\end{aligned}$
if the author(s) chose to include only ran-
domised, double-blind, placebo-controlled
studies, or allocation concealment as in-
clusion criteria); for other types of studies
alternative items will be relevant

\begin{tabular}{lllllll}
\hline (B) The scientific quality of the included & Yes & Yes & Yes & Yes & Yes
\end{tabular}

studies appeared to be meaningful

\begin{tabular}{lllllll}
$\begin{array}{l}\text { (C) Discussion/recognition/awareness of } \\
\text { level of evidence }\end{array}$ & Yes & Yes & Yes & Yes & Yes & Yes \\
\hline
\end{tabular}

(D) Quality of evidence should be rat-

No

No No

No

ed/ranked based on characterised instruments. (Characterised instrument is a created instrument that ranks the level of evidence, e.g. GRADE (Grading of Recommendations Assessment, Development and Evaluation))

\begin{tabular}{lllllll}
\hline Score & 3 & 3 & 3 & 3 & 3 & 3 \\
\hline
\end{tabular}

\section{Was the scientific quality of the included studies used appropriately in formulating conclusions?}

\begin{tabular}{|c|c|c|c|c|c|c|}
\hline $\begin{array}{l}\text { (A) The results of the methodological rigor } \\
\text { and scientific quality should be considered } \\
\text { in the analysis and the conclusions of the } \\
\text { review }\end{array}$ & Yes & Yes & Yes & Yes & Yes & Yes \\
\hline
\end{tabular}

$\begin{array}{llllll}\text { (B) The results of the methodological rigor } & \text { No } & \text { No } & \text { No } & \text { No } & \text { No }\end{array}$
and scientific quality were explicitly stated in formulating recommendations

\begin{tabular}{lcccccc}
$\begin{array}{l}\text { (C) To have conclusions integrated/drives } \\
\text { towards a clinical consensus statement }\end{array}$ & Yes & Yes & Yes & Yes & Yes & Yes \\
\hline $\begin{array}{l}\text { (D) This clinical consensus statement dri- } \\
\text { ves towards revision or confirmation of } \\
\text { clinical practice guidelines }\end{array}$ & No & No & No & Yes & No & No \\
\hline Score & 2 & 2 & 2 & 3 & 2 & 3 \\
\hline
\end{tabular}

\section{Were the methods used to combine the findings of studies appropriate?}


Table 3. R-AMSTAR assessment of included systematic reviews (Continued)
(A) Statement of criteria that were used to Yes
Yes
No
Yes
Yes
Yes decide that the studies analysed were simi- lar enough to be pooled?

$\begin{aligned} & \text { (B) For the pooled results, a test should be } \\ & \text { done to ensure the studies were combin- }\end{aligned}$
able, to assess their homogeneity (i.e. Chi 2
test for homogeneity, 12 statistic)

\begin{tabular}{|c|c|c|c|c|c|c|}
\hline $\begin{array}{l}\text { (C) Is there a recognition of heterogeneity } \\
\text { or lack of thereof }\end{array}$ & Yes & Yes & Yes & Yes & Yes & Yes \\
\hline $\begin{array}{l}\text { (D) If heterogeneity exists a "random-ef- } \\
\text { fects model" should be used or the ratio- } \\
\text { nale (i.e. clinical appropriateness) of com- } \\
\text { bining should be taken into consideration } \\
\text { (i.e. is it sensible to combine?), or stated } \\
\text { explicitly (or both) }\end{array}$ & Yes & Yes & Yes & Yes & Yes & NA \\
\hline $\begin{array}{l}\text { (E) If homogeneity exists, author should } \\
\text { state a rationale or a statistical test }\end{array}$ & Yes & Yes & NA & $N A$ & Yes & NA \\
\hline Score & 4 & 4 & 3 & 4 & 4 & 2 \\
\hline
\end{tabular}

\section{Was the likelihood of publication bias (a.k.a. "file drawer" effect) assessed?}

\begin{tabular}{|c|c|c|c|c|c|c|}
\hline $\begin{array}{l}\text { (A) Recognition of publication bias or file- } \\
\text { drawer effect }\end{array}$ & Yes & Yes & Yes & Yes & Yes & Yes \\
\hline $\begin{array}{l}\text { (B) An assessment of publication bias } \\
\text { should include graphical aids (e.g. funnel } \\
\text { plot, other available tests) }\end{array}$ & Yes & Yes & Yes & Yes & Yes & No \\
\hline $\begin{array}{l}\text { (C) Statistical tests (e.g. Egger regression } \\
\text { test) }\end{array}$ & Yes & Yes & Yes & Yes & Yes & No \\
\hline Score & 4 & 4 & 4 & 4 & 4 & 2 \\
\hline
\end{tabular}

\section{Was the conflict of interest stated?}

\begin{tabular}{|c|c|c|c|c|c|c|}
\hline (A) Statement of sources of support & Yes & Yes & Yes & Yes & Yes & Yes \\
\hline $\begin{array}{l}\text { (B) No conflict of interest. This is subjec- } \\
\text { tive and may require some deduction or } \\
\text { searching }\end{array}$ & Yes & Yes & Yes & Yes & Yes & Yes \\
\hline $\begin{array}{l}\text { (C) An awareness/statement of support or } \\
\text { conflict of interest in the primary inclusion } \\
\text { studies }\end{array}$ & No & No & No & No & No & No \\
\hline Score & 3 & 3 & 3 & 3 & 3 & 3 \\
\hline Total score (n/44) & 39 & 39 & 39 & 41 & 40 & 35 \\
\hline
\end{tabular}

CHD: coronary heart disease; HF: heart failure.

* Studies were screened independently by 2 review authors. Data were extracted by 1 review author and checked by a second review author. 
${ }^{\star \star}$ While the authors did not explicitly state that they searched for reports regardless of publication type, it was clear from the included studies or text (or both) that a search of grey literature was conducted. 


\begin{tabular}{|c|c|c|c|c|c|c|c|}
\hline $\begin{array}{l}\text { Review short title } \\
\text { (reference) }\end{array}$ & $\begin{array}{l}\text { Exercise for } \\
\text { CHD } \\
\text { (Heran 2011) }\end{array}$ & $\begin{array}{l}\text { Exercise for } \\
\text { HF } \\
\text { (Taylor 2014b) }\end{array}$ & $\begin{array}{l}\text { Psychologi- } \\
\text { cal for CHD } \\
\text { (Whalley } \\
2011)\end{array}$ & $\begin{array}{l}\text { Education for } \\
\text { CHD } \\
\text { (Brown 2011) }\end{array}$ & $\begin{array}{l}\text { Home vs. } \\
\text { centre } \\
\text { (Taylor 2014a) }\end{array}$ & $\begin{array}{l}\text { Uptake and } \\
\text { adherence } \\
\text { (Karmali } \\
\text { 2014) }\end{array}$ & Total \\
\hline & \multicolumn{7}{|c|}{ Number of RCTs with low risk of bias (\%) } \\
\hline Random sequence generation & $8(17)$ & $10(30)$ & $7(29)$ & $9(69)$ & $4(24)$ & $9(50)$ & $47(31)$ \\
\hline Allocation concealment & $7(15)$ & $6(18)$ & $7(29)$ & $7(54)$ & $7(41)$ & $8(44)$ & $41(27)$ \\
\hline Groups balanced at baseline & $a_{27}(57)$ & $32(97)$ & $a_{10}(42)$ & $12(92)$ & $14(82)$ & abg (56) & $103(68)$ \\
\hline Outcome blinding & $4(9)$ & $11(33)$ & $5(21)$ & $4(31)$ & $7(41)$ & $5(28)$ & $36(24)$ \\
\hline Selective reporting & $0(0)$ & $31(94)$ & $16(67)$ & $12(92)$ & $16(94)$ & $15(83)$ & $90(59)$ \\
\hline Loss to follow-up $<20 \%$ & $33(70)$ & $29(88)$ & $13(54)$ & $10(77)$ & $11(65)$ & $4(22)$ & $99(65)$ \\
\hline Intention-to-treat analysis & $a_{19}(40)$ & $29(88)$ & $22(92)$ & $11(85)$ & $14(82)$ & ab7 (44) & $101(66)$ \\
\hline $\begin{array}{l}\text { Groups received same treatment apart from } \\
\text { intervention`}\end{array}$ & $a_{21}(45)$ & $21(64)$ & $a_{16}(67)$ & $11(85)$ & $15(88)$ & ab15 (94) & $100(66)$ \\
\hline \multicolumn{8}{|c|}{$\begin{array}{l}\text { CHD: coronary heart disease; HF: heart failure; RCT: randomised controlled trial. } \\
a \text { Risk of bias was not reported within the review, but was assessed by the authors of this overview. } \\
b \text { Denominator }=16 \text { as } 2 \text { studies were unavailable to us as they were unpublished degree dissertations. }\end{array}$} \\
\hline
\end{tabular}


Table 5. Exercise-based cardiac rehabilitation for coronary heart disease

\section{Exercise-based cardiac rehabilitation for coronary heart disease}

Patient or population: people with CHD

Settings:

Intervention: exercise-based CR

\begin{tabular}{|c|c|c|c|c|c|c|}
\hline \multirow[t]{2}{*}{ Outcomes } & \multicolumn{2}{|c|}{ Illustrative comparative risks* $(95 \% \mathrm{CI})$} & \multirow{2}{*}{$\begin{array}{l}\text { Relative ef- } \\
\text { fect } \\
(95 \% \mathrm{CI})\end{array}$} & \multirow{2}{*}{$\begin{array}{l}\text { No of par- } \\
\text { ticipants } \\
\text { (studies) }\end{array}$} & \multirow{2}{*}{$\begin{array}{l}\text { Quality of } \\
\text { the evi- } \\
\text { dence } \\
\text { (GRADE) }\end{array}$} & \multirow[t]{2}{*}{ Comments } \\
\hline & Assumed risk & Corresponding risk & & & & \\
\hline & Control & Exercise-based CR & & & & \\
\hline \multirow{3}{*}{$\begin{array}{l}\text { Total mortality } \\
\text { Follow-up: 6-12 } \\
\text { months }\end{array}$} & \multicolumn{2}{|c|}{ Study population } & \multirow{3}{*}{$\begin{array}{l}\text { RR } 0.82 \\
\text { (0.67 to } 1.01)\end{array}$} & \multirow{3}{*}{$\begin{array}{l}6000 \\
\text { (19 studies) }\end{array}$} & \multirow{3}{*}{$\begin{array}{l}\oplus \oplus \ominus \ominus \\
\text { low } 1,2\end{array}$} & - \\
\hline & 65 per 1000 & $\begin{array}{l}\mathbf{5 3} \text { per } 1000 \\
(43 \text { to } 65)\end{array}$ & & & & \\
\hline & Moderate & & & & & \\
\hline \multirow{4}{*}{$\begin{array}{l}\text { Total mortality } \\
\text { Follow-up: } 12-120 \\
\text { months }\end{array}$} & \multicolumn{2}{|c|}{ Study population } & \multirow{4}{*}{$\begin{array}{l}\text { RR } 0.87 \\
(0.75 \text { to } 0.99)\end{array}$} & \multirow{4}{*}{$\begin{array}{l}5790 \\
\text { (16 studies) }\end{array}$} & \multirow{4}{*}{$\begin{array}{l}\oplus \oplus \oplus \ominus \\
\text { moderate }^{1}\end{array}$} & - \\
\hline & 126 per 1000 & $\begin{array}{l}109 \text { per } 1000 \\
(94 \text { to } 125)\end{array}$ & & & & \\
\hline & \multicolumn{2}{|l|}{ Moderate } & & & & \\
\hline & - & - & & & & \\
\hline \multirow{4}{*}{$\begin{array}{l}\text { Cardiovascular } \\
\text { mortality } \\
\text { Follow-up: 6-12 } \\
\text { months }\end{array}$} & \multicolumn{2}{|c|}{ Study population } & \multirow{4}{*}{$\begin{array}{l}\text { RR } 0.93 \\
\text { (0.71 to } 1.21)\end{array}$} & \multirow{4}{*}{$\begin{array}{l}4130 \\
\text { (9 studies) }\end{array}$} & \multirow{4}{*}{$\begin{array}{l}\oplus \oplus \ominus \ominus \\
\text { low }^{1,2}\end{array}$} & - \\
\hline & 51 per 1000 & $\begin{array}{l}\mathbf{4 8} \text { per } \mathbf{1 0 0 0} \\
(36 \text { to } 62)\end{array}$ & & & & \\
\hline & \multicolumn{2}{|l|}{ Moderate } & & & & \\
\hline & - & - & & & & \\
\hline \multirow{4}{*}{$\begin{array}{l}\text { Cardiovascular } \\
\text { mortality } \\
\text { Follow-up: } 12-120 \\
\text { months }\end{array}$} & \multicolumn{2}{|c|}{ Study population } & \multirow{4}{*}{$\begin{array}{l}\text { RR } 0.74 \\
(0.63 \text { to } 0.87 \text { ) }\end{array}$} & \multirow{4}{*}{$\begin{array}{l}4757 \\
\text { (12 studies) }\end{array}$} & \multirow{4}{*}{$\begin{array}{l}\oplus \oplus \oplus \ominus \\
\text { moderate }^{1}\end{array}$} & - \\
\hline & 129 per 1000 & $\begin{array}{l}\mathbf{9 6} \text { per } \mathbf{1 0 0 0} \\
\text { (81 to } 112)\end{array}$ & & & & \\
\hline & \multicolumn{2}{|l|}{ Moderate } & & & & \\
\hline & - & - & & & & \\
\hline \multirow{3}{*}{$\begin{array}{l}\text { Hospitalisations } \\
\text { Follow-up: } 6-12 \\
\text { months }\end{array}$} & \multicolumn{2}{|c|}{ Study population } & \multirow{3}{*}{$\begin{array}{l}\text { RR } 0.69 \\
(0.51 \text { to } 0.93)\end{array}$} & \multirow{3}{*}{$\begin{array}{l}463 \\
\text { (4 studies) }\end{array}$} & \multirow{3}{*}{$\begin{array}{l}\oplus \oplus \oplus \ominus \\
\text { moderate }^{1}\end{array}$} & - \\
\hline & 324 per 1000 & $\begin{array}{l}\mathbf{2 2 4} \text { per } \mathbf{1 0 0 0} \\
\text { (165 to } 302)\end{array}$ & & & & \\
\hline & Moderate & & & & & \\
\hline
\end{tabular}


Table 5. Exercise-based cardiac rehabilitation for coronary heart disease (Continued)

\begin{tabular}{|c|c|c|c|c|c|c|}
\hline \multirow{4}{*}{$\begin{array}{l}\text { Hospitalisations } \\
\text { Follow-up: } 12-48 \\
\text { months }\end{array}$} & \multicolumn{2}{|c|}{ Study population } & \multirow{4}{*}{$\begin{array}{l}\text { RR } 0.98 \\
(0.87 \text { to } 1.11)\end{array}$} & \multirow{4}{*}{$\begin{array}{l}2009 \\
\text { (7 studies) }\end{array}$} & \multirow{4}{*}{$\begin{array}{l}\oplus \oplus \ominus \ominus \\
\text { low }^{1,3}\end{array}$} & \multirow[t]{4}{*}{-} \\
\hline & 342 per 1000 & $\begin{array}{l}\mathbf{3 3 5} \text { per } \mathbf{1 0 0 0} \\
\text { (297 to } 379)\end{array}$ & & & & \\
\hline & \multicolumn{2}{|l|}{ Moderate } & & & & \\
\hline & - & - & & & & \\
\hline \multirow{4}{*}{$\begin{array}{l}\text { MI } \\
\text { Follow-up: 6-12 } \\
\text { months }\end{array}$} & \multicolumn{2}{|c|}{ Study population } & \multirow{4}{*}{$\begin{array}{l}\text { RR } 0.92 \\
\text { (0.7 to } 1.22 \text { ) }\end{array}$} & \multirow{4}{*}{$\begin{array}{l}4216 \\
\text { (12 studies) }\end{array}$} & \multirow{4}{*}{$\begin{array}{l}\oplus \odot \Theta \odot \\
\text { very } \\
\text { low } 1,2,4\end{array}$} & - \\
\hline & 45 per 1000 & $\begin{array}{l}\mathbf{4 1} \text { per } \mathbf{1 0 0 0} \\
\text { (32 to } 55)\end{array}$ & & & & \\
\hline & Moderate & & & & & \\
\hline & - & - & & & & \\
\hline \multirow{4}{*}{$\begin{array}{l}\text { MI } \\
\text { Follow-up: } 12-120 \\
\text { months }\end{array}$} & \multicolumn{2}{|c|}{ Study population } & \multirow{4}{*}{$\begin{array}{l}\text { RR } 0.97 \\
\text { (0.82 to } 1.15)\end{array}$} & \multirow{4}{*}{$\begin{array}{l}5682 \\
\text { (16 studies) }\end{array}$} & \multirow{4}{*}{$\begin{array}{l}\oplus \oplus \ominus \ominus \\
\text { low }^{1,4}\end{array}$} & - \\
\hline & 89 per 1000 & $\begin{array}{l}\mathbf{8 7} \text { per } 1000 \\
\text { (73 to } 103)\end{array}$ & & & & \\
\hline & Moderate & & & & & \\
\hline & - & - & & & & \\
\hline \multirow{4}{*}{$\begin{array}{l}\text { CABG } \\
\text { Follow-up: 6-12 } \\
\text { months }\end{array}$} & \multicolumn{2}{|c|}{ Study population } & \multirow{4}{*}{$\begin{array}{l}\text { RR } 0.91 \\
(0.67 \text { to } 1.24)\end{array}$} & \multirow{4}{*}{$\begin{array}{l}2312 \\
\text { (14 studies) }\end{array}$} & \multirow{4}{*}{$\begin{array}{l}\oplus \oplus \odot \ominus \\
\text { low } 1,2\end{array}$} & - \\
\hline & 67 per 1000 & $\begin{array}{l}\mathbf{6 1} \text { per } \mathbf{1 0 0 0} \\
(45 \text { to } 83)\end{array}$ & & & & \\
\hline & \multicolumn{2}{|l|}{ Moderate } & & & & \\
\hline & - & - & & & & \\
\hline \multirow{4}{*}{$\begin{array}{l}\text { CABG } \\
\text { Follow-up: } 12-120 \\
\text { months }\end{array}$} & \multicolumn{2}{|c|}{ Study population } & \multirow{4}{*}{$\begin{array}{l}\text { RR } 0.93 \\
\text { (0.68 to } 1.27 \text { ) }\end{array}$} & \multirow{4}{*}{$\begin{array}{l}2189 \\
\text { (9 studies) }\end{array}$} & \multirow{4}{*}{$\begin{array}{l}\oplus \oplus \ominus \ominus \\
\text { low } \mathbf{w}^{1,2}\end{array}$} & - \\
\hline & 69 per 1000 & $\begin{array}{l}64 \text { per } 1000 \\
(47 \text { to } 88)\end{array}$ & & & & \\
\hline & \multicolumn{2}{|l|}{ Moderate } & & & & \\
\hline & - & - & & & & \\
\hline \multirow{4}{*}{$\begin{array}{l}\text { PTCA } \\
\text { Follow-up: 6-12 } \\
\text { months }\end{array}$} & \multicolumn{2}{|c|}{ Study population } & \multirow{4}{*}{$\begin{array}{l}\text { RR } 1.02 \\
(0.69 \text { to } 1.5)\end{array}$} & \multirow{4}{*}{$\begin{array}{l}1328 \\
\text { (7 studies) }\end{array}$} & \multirow{4}{*}{$\begin{array}{l}\oplus \oplus \ominus \ominus \\
\text { low }^{1,2}\end{array}$} & - \\
\hline & 69 per 1000 & $\begin{array}{l}\mathbf{7 1} \text { per } 1000 \\
(48 \text { to } 104)\end{array}$ & & & & \\
\hline & Moderate & & & & & \\
\hline & - & - & & & & \\
\hline
\end{tabular}


Table 5. Exercise-based cardiac rehabilitation for coronary heart disease (Continued)

\begin{tabular}{|c|c|c|c|c|c|}
\hline \multirow{2}{*}{$\begin{array}{l}\text { PTCA } \\
\text { Follow-up: } 12-48 \\
\text { months }\end{array}$} & \multicolumn{2}{|c|}{ Study population } & \multirow{2}{*}{$\begin{array}{l}\text { RR } 0.89 \\
(0.66 \text { to } 1.19)\end{array}$} & \multirow{2}{*}{$\begin{array}{l}1322 \\
\text { (6 studies) }\end{array}$} & \multirow{2}{*}{$\begin{array}{l}\oplus \oplus \ominus \ominus \\
\text { low } 1,2\end{array}$} \\
\hline & 124 per 1000 & $\begin{array}{l}\mathbf{1 1 0} \text { per } \mathbf{1 0 0 0} \\
(82 \text { to } 147)\end{array}$ & & & \\
\hline
\end{tabular}

\footnotetext{
*The basis for the assumed risk (e.g. the median control group risk across studies) is provided in footnotes. The corresponding risk (and its $95 \%$ confidence interval) is based on the assumed risk in the comparison group and the relative effect of the intervention (and its $95 \% \mathrm{Cl}$ ).

CABG: coronary artery bypass graft; CHD: coronary heart disease; CI: confidence interval; CR: cardiac rehabilitation; MI: myocardial infarction; PTCA: percutaneous transluminal coronary angioplasty; RR: risk ratio.
}

\footnotetext{
GRADE Working Group grades of evidence

High quality: Further research is very unlikely to change our confidence in the estimate of effect. the estimate. change the estimate.

Very low quality: We are very uncertain about the estimate.

1 Random sequence generation and allocation concealment were poorly described; bias likely.

2 The $95 \%$ Cls include both no effect and appreciable benefit or harm (i.e. RR $<0.75$ or $>1.25$ ).

3 Moderate heterogeneity $(12>50 \%)$.

4 Funnel plots or Egger test (or both) suggest evidence of asymmetry.
}

Moderate quality: Further research is likely to have an important impact on our confidence in the estimate of effect and may change

Low quality: Further research is very likely to have an important impact on our confidence in the estimate of effect and is likely to

\section{Table 6. Exercise-based cardiac rehabilitation for heart disease}

\section{Exercise-based cardiac rehabilitation for heart failure}

Patient or population: people with HF

\section{Settings:}

Intervention: exercise-based CR

\begin{tabular}{|c|c|c|c|c|c|c|}
\hline \multirow[t]{2}{*}{ Outcomes } & \multicolumn{2}{|c|}{ Illustrative comparative risks* $(95 \% \mathrm{CI})$} & \multirow{2}{*}{$\begin{array}{l}\text { Relative } \\
\text { effect } \\
(95 \% \mathrm{CI})\end{array}$} & \multirow{2}{*}{$\begin{array}{l}\text { No of par- } \\
\text { ticipants } \\
\text { (studies) }\end{array}$} & \multirow{2}{*}{$\begin{array}{l}\text { Quality of } \\
\text { the evi- } \\
\text { dence } \\
\text { (GRADE) }\end{array}$} & \multirow[t]{2}{*}{ Comments } \\
\hline & $\begin{array}{l}\text { Assumed } \\
\text { risk }\end{array}$ & Corresponding risk & & & & \\
\hline & Control & Exercise-based CR & & & & \\
\hline \multirow{4}{*}{$\begin{array}{l}\text { Total mortality } \\
\text { Follow-up: 6-12 } \\
\text { months }\end{array}$} & \multicolumn{2}{|c|}{ Study population } & \multirow{4}{*}{$\begin{array}{l}\text { RR } 0.93 \\
(0.69 \text { to } \\
1.27)\end{array}$} & \multirow{4}{*}{$\begin{array}{l}1871 \\
\text { (25 studies) }\end{array}$} & \multirow{4}{*}{$\begin{array}{l}\oplus \oplus \ominus \ominus \\
\text { low } 1,2\end{array}$} & - \\
\hline & $\begin{array}{l}75 \text { per } \\
1000\end{array}$ & $\begin{array}{l}\mathbf{7 0} \text { per } 1000 \\
(52 \text { to } 96)\end{array}$ & & & & \\
\hline & \multicolumn{2}{|l|}{ Moderate } & & & & \\
\hline & - & - & & & & \\
\hline Total mortality & \multicolumn{2}{|c|}{ Study population } & RR 0.88 & $\begin{array}{l}2845 \\
\text { (6 studies) }\end{array}$ & $\begin{array}{l}\oplus \oplus \ominus \ominus \\
\text { low } 1,2\end{array}$ & - \\
\hline
\end{tabular}


Table 6. Exercise-based cardiac rehabilitation for heart disease (Continued)

$\begin{array}{llll}\text { Follow-up: 12-120 } & \mathbf{1 9 6} \text { per } & \mathbf{1 7 3} \text { per } \mathbf{1 0 0 0} & \text { (0.75 to } \\ \text { months } & \mathbf{1 0 0 0} & (147 \text { to } 200) & 1.02) \\ & & & \end{array}$

\section{Moderate}

\begin{tabular}{|c|c|c|c|c|c|c|}
\hline \multirow{4}{*}{$\begin{array}{l}\text { Hospitalisations } \\
\text { Follow-up: } 6-12 \\
\text { months }\end{array}$} & \multicolumn{2}{|c|}{ Study population } & \multirow{4}{*}{$\begin{array}{l}\mathbf{R R} \mathbf{0 . 7 5} \\
(0.62 \text { to } \\
0.92)\end{array}$} & \multirow{4}{*}{$\begin{array}{l}1328 \\
\text { (15 studies) }\end{array}$} & \multirow{4}{*}{$\begin{array}{l}\oplus \oplus \oplus \ominus \\
\text { moderate }^{1}\end{array}$} & \multirow[t]{4}{*}{ - } \\
\hline & $\begin{array}{l}227 \text { per } \\
1000\end{array}$ & $\begin{array}{l}\mathbf{1 7 0} \text { per } \mathbf{1 0 0 0} \\
(141 \text { to } 209)\end{array}$ & & & & \\
\hline & \multicolumn{2}{|c|}{ Moderate } & & & & \\
\hline & - & - & & & & \\
\hline \multirow{4}{*}{$\begin{array}{l}\text { Hospitalisations } \\
\text { Follow-up: } 12-74 \\
\text { months }\end{array}$} & \multicolumn{2}{|c|}{ Study population } & \multirow{4}{*}{$\begin{array}{l}\text { RR } 0.92 \\
(0.66 \text { to } \\
1.29)\end{array}$} & \multirow{4}{*}{$\begin{array}{l}2722 \\
\text { (5 studies) }\end{array}$} & \multirow{4}{*}{$\begin{array}{l}\oplus \Theta \Theta \Theta \\
\text { very } \\
\text { low } 1,2,3\end{array}$} & - \\
\hline & $\begin{array}{l}604 \text { per } \\
1000\end{array}$ & $\begin{array}{l}\mathbf{5 5 6} \text { per } \mathbf{1 0 0 0} \\
\text { (399 to } 779)\end{array}$ & & & & \\
\hline & \multicolumn{2}{|c|}{ Moderate } & & & & \\
\hline & - & - & & & & \\
\hline \multirow{4}{*}{$\begin{array}{l}\text { Hospitalisations (HF- } \\
\text { specific admissions) } \\
\text { Follow-up: } 12-120 \\
\text { months }\end{array}$} & \multicolumn{2}{|c|}{ Study population } & \multirow{4}{*}{$\begin{array}{l}\text { RR } 0.61 \\
(0.46 \text { to } 0.8)\end{array}$} & \multirow{4}{*}{$\begin{array}{l}1036 \\
\text { (12 studies) }\end{array}$} & \multirow{4}{*}{$\begin{array}{l}\oplus \oplus \oplus \ominus \\
\text { moder- } \\
\text { ate }^{1,2}\end{array}$} & - \\
\hline & $\begin{array}{l}182 \text { per } \\
1000\end{array}$ & $\begin{array}{l}\mathbf{1 1 1} \text { per } \mathbf{1 0 0 0} \\
\text { (84 to } 145)\end{array}$ & & & & \\
\hline & \multicolumn{2}{|c|}{ Moderate } & & & & \\
\hline & - & - & & & & \\
\hline $\begin{array}{l}\text { HRQoL } \\
\text { MLWHF score } \\
\text { Follow-up: 6-12 } \\
\text { months }\end{array}$ & - & $\begin{array}{l}\text { The mean HRQoL in the inter- } \\
\text { vention groups was } \\
\mathbf{5 . 8} \text { lower } \\
\text { ( } 9.21 \text { to } 2.44 \text { lower) }\end{array}$ & - & $\begin{array}{l}1270 \\
\text { (13 studies) }\end{array}$ & $\begin{array}{l}\oplus \odot \odot \ominus \\
\text { very } \\
\text { low } 1,3,4\end{array}$ & - \\
\hline $\begin{array}{l}\text { HRQoL } \\
\text { All HRQoL measures } \\
\text { Follow-up: 12-120 } \\
\text { months }\end{array}$ & - & $\begin{array}{l}\text { The mean } H R Q o L \text { in the inter- } \\
\text { vention groups was } \\
\mathbf{0 . 4 6} \text { lower } \\
\text { ( } 0.66 \text { to } 0.26 \text { lower) }\end{array}$ & - & $\begin{array}{l}3240 \\
\text { (13 studies) }\end{array}$ & $\begin{array}{l}\oplus \ominus \odot \odot \\
\text { very } \\
\text { low } 1,2,3,4\end{array}$ & - \\
\hline $\begin{array}{l}\text { HRQoL } \\
\text { MLWHF } \\
\text { Follow-up: 6-120 } \\
\text { months }\end{array}$ & - & $\begin{array}{l}\text { The mean HRQoL in the inter- } \\
\text { vention groups was } \\
\mathbf{9 . 4 9} \text { lower } \\
\text { (17.48 to } 1.5 \text { lower) }\end{array}$ & - & $\begin{array}{l}329 \\
\text { (20 studies) }\end{array}$ & $\begin{array}{l}\oplus \odot \odot \odot \\
\text { very } \\
\text { low } 1,2,3,4\end{array}$ & - \\
\hline
\end{tabular}

*The basis for the assumed risk (e.g. the median control group risk across studies) is provided in footnotes. The corresponding risk (and its 95\% confidence interval) is based on the assumed risk in the comparison group and the relative effect of the intervention (and its $95 \% \mathrm{Cl}$ ).

Cl: confidence interval; CR: cardiac rehabilitation; HF: heart failure; HRQoL: health-related quality of life; MLWHF: Minnesota Living with Heart Failure questionnaire; RR: risk ratio.

GRADE Working Group grades of evidence

High quality: Further research is very unlikely to change our confidence in the estimate of effect. 
Table 6. Exercise-based cardiac rehabilitation for heart disease (Continued)

Moderate quality: Further research is likely to have an important impact on our confidence in the estimate of effect and may change the estimate.

Low quality: Further research is very likely to have an important impact on our confidence in the estimate of effect and is likely to change the estimate.

Very low quality: We are very uncertain about the estimate.

1 Random sequence generation and allocation concealment were poorly described; bias likely.

2 The $95 \% \mathrm{Cls}$ include both no effect and appreciable benefit or harm (i.e. RR $<0.75$ or $>1.25$ ).

3 Moderate heterogeneity $(12>50 \%)$.

4 Funnel plots or Egger test (or both) suggest evidence of asymmetry.

Table 7. Psychological-based interventions for coronary heart disease

\section{Psychological-based interventions for coronary heart disease}

\section{Patient or population: people with CHD}

Settings:

Intervention: psychological-based interventions

\begin{tabular}{|c|c|c|c|c|c|c|}
\hline \multirow[t]{2}{*}{ Outcomes } & \multicolumn{2}{|c|}{ Illustrative comparative risks* $(95 \% \mathrm{Cl})$} & \multirow{2}{*}{$\begin{array}{l}\text { Relative ef- } \\
\text { fect } \\
(95 \% \mathrm{CI})\end{array}$} & \multirow{2}{*}{$\begin{array}{l}\text { No of par- } \\
\text { ticipants } \\
\text { (studies) }\end{array}$} & \multirow{2}{*}{$\begin{array}{l}\text { Quality of } \\
\text { the evi- } \\
\text { dence } \\
\text { (GRADE) }\end{array}$} & \multirow[t]{2}{*}{ Comments } \\
\hline & Assumed risk & Corresponding risk & & & & \\
\hline & Control & $\begin{array}{l}\text { Psychological-based inter- } \\
\text { ventions }\end{array}$ & & & & \\
\hline \multirow{4}{*}{$\begin{array}{l}\text { Total mortality } \\
\text { Follow-up: 6-12 } \\
\text { months }\end{array}$} & \multicolumn{2}{|c|}{ Study population } & \multirow{4}{*}{$\begin{array}{l}\text { RR } 0.89 \\
(0.75 \text { to } 1.05)\end{array}$} & \multirow{4}{*}{$\begin{array}{l}6852 \\
\text { (17 studies) }\end{array}$} & \multirow{4}{*}{$\begin{array}{l}\oplus \oplus \Theta \Theta \\
\text { low } 1,2\end{array}$} & - \\
\hline & 93 per 1000 & $\begin{array}{l}\mathbf{8 3} \text { per } \mathbf{1 0 0 0} \\
(70 \text { to } 98)\end{array}$ & & & & \\
\hline & \multicolumn{2}{|l|}{ Moderate } & & & & \\
\hline & - & - & & & & \\
\hline \multirow{4}{*}{$\begin{array}{l}\text { Cardiovascular } \\
\text { mortality } \\
\text { Follow-up: 6-15 } \\
\text { months }\end{array}$} & \multicolumn{2}{|c|}{ Study population } & \multirow{4}{*}{$\begin{array}{l}\text { RR } 0.80 \\
(0.64 \text { to } 1)\end{array}$} & \multirow{4}{*}{$\begin{array}{l}3893 \\
\text { (5 studies) }\end{array}$} & \multirow{4}{*}{$\begin{array}{l}\oplus \oplus \ominus \ominus \\
\text { low } 1,2\end{array}$} & - \\
\hline & 85 per 1000 & $\begin{array}{l}\mathbf{6 8} \text { per } \mathbf{1 0 0 0} \\
\text { (55 to } 85)\end{array}$ & & & & \\
\hline & \multicolumn{2}{|l|}{ Moderate } & & & & \\
\hline & - & - & & & & \\
\hline \multirow{3}{*}{$\begin{array}{l}\text { MI (non-fatal) } \\
\text { Follow-up: 6-15 } \\
\text { months }\end{array}$} & \multicolumn{2}{|c|}{ Study population } & \multirow{3}{*}{$\begin{array}{l}\text { RR } 0.87 \\
(0.67 \text { to } 1.13)\end{array}$} & \multirow{3}{*}{$\begin{array}{l}7534 \\
\text { (12 studies) }\end{array}$} & \multirow{3}{*}{$\begin{array}{l}\oplus \oplus \ominus \ominus \\
\text { low } 1,2\end{array}$} & - \\
\hline & 83 per 1000 & $\begin{array}{l}\mathbf{7 2} \text { per } \mathbf{1 0 0 0} \\
(55 \text { to } 94)\end{array}$ & & & & \\
\hline & Moderate & & & & & \\
\hline
\end{tabular}


Table 7. Psychological-based interventions for coronary heart disease (Continued)

\begin{tabular}{|c|c|c|c|c|c|}
\hline \multirow{3}{*}{$\begin{array}{l}\text { Revascularisation } \\
\text { (CABG and PTCA } \\
\text { combined) } \\
\text { Follow-up: 6-15 } \\
\text { months }\end{array}$} & \multicolumn{2}{|c|}{ Study population } & \multirow{3}{*}{$\begin{array}{l}\text { RR } 0.95 \\
\text { (0.8 to } 1.13)\end{array}$} & \multirow{3}{*}{$\begin{array}{l}6670 \\
\text { (12 studies) }\end{array}$} & \multirow{3}{*}{$\begin{array}{l}\oplus \oplus \oplus \ominus \\
\text { moderate }^{1}\end{array}$} \\
\hline & 121 per 1000 & $\begin{array}{l}\mathbf{1 1 5} \text { per } \mathbf{1 0 0 0} \\
\text { (97 to } 137)\end{array}$ & & & \\
\hline & Moderate & & & & \\
\hline
\end{tabular}

*The basis for the assumed risk (e.g. the median control group risk across studies) is provided in footnotes. The corresponding risk (and its $95 \%$ confidence interval) is based on the assumed risk in the comparison group and the relative effect of the intervention (and its 95\% Cl).

CABG: coronary artery bypass graft; CHD: coronary heart disease; Cl: confidence interval; MI: myocardial infarction; PTCA: percutaneous transluminal coronary angioplasty; RR: risk ratio.

GRADE Working Group grades of evidence

High quality: Further research is very unlikely to change our confidence in the estimate of effect.

Moderate quality: Further research is likely to have an important impact on our confidence in the estimate of effect and may change the estimate.

Low quality: Further research is very likely to have an important impact on our confidence in the estimate of effect and is likely to change the estimate.

Very low quality: We are very uncertain about the estimate.

1 Random sequence generation and allocation concealment were poorly described; bias likely.

2 The 95\% Cls include both no effect and appreciable benefit or harm (i.e. RR $<0.75$ or $>1.25$ ).

\section{Table 8. Education-based interventions for coronary heart disease}

\section{Education-based interventions forcoronary heart disease}

Patient or population: people with CHD

Settings:

Intervention: education-based interventions

\begin{tabular}{|c|c|c|c|c|c|c|}
\hline \multirow[t]{2}{*}{ Outcomes } & \multicolumn{2}{|c|}{ Illustrative comparative risks* $(95 \% \mathrm{Cl})$} & \multirow{2}{*}{$\begin{array}{l}\text { Relative effect } \\
(95 \% \mathrm{Cl})\end{array}$} & \multirow{2}{*}{$\begin{array}{l}\text { No of partic- } \\
\text { ipants } \\
\text { (studies) }\end{array}$} & \multirow{2}{*}{$\begin{array}{l}\text { Quality of } \\
\text { the evi- } \\
\text { dence } \\
\text { (GRADE) }\end{array}$} & \multirow[t]{2}{*}{ Comments } \\
\hline & Assumed risk & Corresponding risk & & & & \\
\hline & Control & $\begin{array}{l}\text { Education-based interven- } \\
\text { tions }\end{array}$ & & & & \\
\hline \multirow{4}{*}{$\begin{array}{l}\text { Total mor- } \\
\text { tality } \\
\text { deaths } \\
\text { Follow-up: } \\
\text { median } 18 \\
\text { months }\end{array}$} & \multicolumn{2}{|c|}{ Study population } & \multirow{4}{*}{$\begin{array}{l}\mathbf{R R} \mathbf{0 . 7 9} \\
(0.55 \text { to } 1.13)\end{array}$} & \multirow{4}{*}{$\begin{array}{l}2330 \\
\text { (6 studies) }\end{array}$} & \multirow{4}{*}{$\begin{array}{l}\oplus \oplus \oplus \ominus \\
\text { moderate }^{1}\end{array}$} & - \\
\hline & 96 per 1000 & $\begin{array}{l}76 \text { per } 1000 \\
(53 \text { to } 108)\end{array}$ & & & & \\
\hline & Moderate & & & & & \\
\hline & - & - & & & & \\
\hline \multirow{2}{*}{$\begin{array}{l}\text { Hospitali- } \\
\text { sations }\end{array}$} & Study popula & & \multirow{2}{*}{$\begin{array}{l}\text { RR } 0.83 \\
(0.65 \text { to } 1.07)\end{array}$} & \multirow{2}{*}{$\begin{array}{l}12,905 \\
\text { (4 studies) }\end{array}$} & \multirow{2}{*}{$\begin{array}{l}\oplus \oplus \oplus \odot \\
\text { moderate }^{1}\end{array}$} & - \\
\hline & 64 per 1000 & $\begin{array}{l}\mathbf{5 3} \text { per } \mathbf{1 0 0 0} \\
(41 \text { to } 68)\end{array}$ & & & & \\
\hline
\end{tabular}


Table 8. Education-based interventions for coronary heart disease (Continued)

\begin{tabular}{|c|c|c|c|c|c|}
\hline & Moderate & & & & \\
\hline & - & - & & & \\
\hline MI & Study popula & & RR 0.63 & 209 & $\oplus \Theta \Theta \Theta$ \\
\hline & 118 per 1000 & $\begin{array}{l}\mathbf{7 4} \text { per } 1000 \\
\text { (31 to } 174)\end{array}$ & & & \\
\hline & Moderate & & & & \\
\hline & - & - & & & \\
\hline CABG & Study popula & & RR 0.58 & 209 & $\oplus \oplus \ominus \ominus$ \\
\hline & 78 per 1000 & $\begin{array}{l}\mathbf{4 5} \text { per } \mathbf{1 0 0 0} \\
(15 \text { to } 134)\end{array}$ & & & \\
\hline & Moderate & & & & \\
\hline & - & - & & & \\
\hline All-cause & Study populat & & RR 1.03 & 2862 & $\oplus \oplus \oplus \odot$ \\
\hline & 181 per 1000 & $\begin{array}{l}\mathbf{1 8 6} \text { per } \mathbf{1 0 0 0} \\
(150 \text { to } 230)\end{array}$ & & & \\
\hline & Moderate & & & & \\
\hline
\end{tabular}

\footnotetext{
*The basis for the assumed risk (e.g. the median control group risk across studies) is provided in footnotes. The corresponding risk (and its 95\% confidence interval) is based on the assumed risk in the comparison group and the relative effect of the intervention (and its $95 \% \mathrm{Cl}$ ).

CABG: coronary artery bypass graft; CHD: coronary heart disease; CI: confidence interval; MI: myocardial infarction; RR: risk ratio.
}

GRADE Working Group grades of evidence

High quality: Further research is very unlikely to change our confidence in the estimate of effect.

Moderate quality: Further research is likely to have an important impact on our confidence in the estimate of effect and may change the estimate.

Low quality: Further research is very likely to have an important impact on our confidence in the estimate of effect and is likely to change the estimate.

Very low quality: We are very uncertain about the estimate.

1 The $95 \%$ Cls include both no effect and appreciable benefit or harm (i.e. RR $<0.75$ or $>1.25$ ).

2 The $95 \%$ Cls include both no effect and substantial benefit or harm (i.e. RR $<0.50$ or $>1.50$ ).

Table 9. Home-based cardiac rehabilitation compared with centre-based cardiac rehabilitation for heart disease

\section{Home-based cardiac rehabilitation compared with centre-based cardiac rehabilitation for heart disease}

Patient or population: people with heart disease

Settings:

Intervention: home-based CR

Comparison: centre-based CR 
Table 9. Home-based cardiac rehabilitation compared with centre-based cardiac rehabilitation for heart

\begin{tabular}{|c|c|c|c|c|c|c|}
\hline \multirow[t]{2}{*}{$\begin{array}{l}\text { disease (Continued) } \\
\text { Outcomes }\end{array}$} & \multicolumn{2}{|c|}{ Illustrative comparative risks* $(95 \% \mathrm{Cl})$} & \multirow{2}{*}{$\begin{array}{l}\text { Relative ef- } \\
\text { fect } \\
(95 \% \mathrm{CI})\end{array}$} & \multirow{2}{*}{$\begin{array}{l}\text { No of par- } \\
\text { ticipants } \\
\text { (studies) }\end{array}$} & \multirow{2}{*}{$\begin{array}{l}\text { Quality of } \\
\text { the evi- } \\
\text { dence } \\
\text { (GRADE) }\end{array}$} & \multirow[t]{2}{*}{ Comments } \\
\hline & Assumed risk & Corresponding risk & & & & \\
\hline & Centre-based CR & Home-based CR & & & & \\
\hline \multirow{4}{*}{$\begin{array}{l}\text { Total mortality } \\
\text { Follow-up: 3-12 } \\
\text { months }\end{array}$} & Study population & & \multirow{4}{*}{$\begin{array}{l}\text { RR } \mathbf{0 . 7 9} \\
(0.43 \text { to } 1.47)\end{array}$} & \multirow{4}{*}{$\begin{array}{l}1166 \\
\text { (7 studies) }\end{array}$} & \multirow{4}{*}{$\begin{array}{l}\oplus \oplus \ominus \ominus \\
\operatorname{low}^{1,2}\end{array}$} & - \\
\hline & 27 per 1000 & $\begin{array}{l}\mathbf{2 2} \text { per } \mathbf{1 0 0 0} \\
(12 \text { to } 40)\end{array}$ & & & & \\
\hline & Moderate & & & & & \\
\hline & - & - & & & & \\
\hline \multirow{3}{*}{$\begin{array}{l}\text { All-cause with- } \\
\text { drawal } \\
\text { Follow-up: medi- } \\
\text { an } 6 \text { months }\end{array}$} & Study population & & \multirow{3}{*}{$\begin{array}{l}\text { RR } 1.04 \\
(1.01 \text { to } 1.07)\end{array}$} & \multirow{3}{*}{$\begin{array}{l}1984 \\
\text { (18 studies) }\end{array}$} & \multirow{3}{*}{$\begin{array}{l}\oplus \oplus \oplus \ominus \\
\text { moderate }^{1}\end{array}$} & - \\
\hline & 874 per 1000 & $\begin{array}{l}\mathbf{9 0 9} \text { per } \mathbf{1 0 0 0} \\
\text { (883 to } 936)\end{array}$ & & & & \\
\hline & Moderate & & & & & \\
\hline
\end{tabular}

\footnotetext{
*The basis for the assumed risk (e.g. the median control group risk across studies) is provided in footnotes. The corresponding risk (and its $95 \%$ confidence interval) is based on the assumed risk in the comparison group and the relative effect of the intervention (and its 95\% Cl).

Cl: confidence interval; CR: cardiac rehabilitation; RR: risk ratio.
}

\section{GRADE Working Group grades of evidence}

High quality: Further research is very unlikely to change our confidence in the estimate of effect.

Moderate quality: Further research is likely to have an important impact on our confidence in the estimate of effect and may change the estimate.

Low quality: Further research is very likely to have an important impact on our confidence in the estimate of effect and is likely to change the estimate.

Very low quality: We are very uncertain about the estimate.

1 Random sequence generation and allocation concealment were poorly described; bias likely.

2 The $95 \%$ Cls include both no effect and appreciable benefit or harm (i.e. $R R<0.75$ or $>1.25$ ).

Table 10. Summary of outcome results across Cochrane systematic reviews

\begin{tabular}{|c|c|c|c|c|c|c|}
\hline $\begin{array}{l}\text { Review } \\
\text { short title } \\
\text { (reference) }\end{array}$ & $\begin{array}{l}\text { Exercise for CHD } \\
(\text { Heran 2011) }\end{array}$ & $\begin{array}{l}\text { Exercise for } \\
\text { HF } \\
\text { (Taylor 2014b) }\end{array}$ & $\begin{array}{l}\text { Psycho- } \\
\text { logical for } \\
\text { CHD } \\
\text { (Whalley } \\
2011)\end{array}$ & $\begin{array}{l}\text { Education for CHD } \\
\text { (Brown 2011) }\end{array}$ & $\begin{array}{l}\text { Home vs. centre } \\
\text { (Taylor 2014a) }\end{array}$ & $\begin{array}{l}\text { Uptake and } \\
\text { adherence } \\
\text { (Karmali } \\
2014 \text { ) }\end{array}$ \\
\hline $\begin{array}{l}\text { Total mor- } \\
\text { tality }\end{array}$ & $\begin{array}{l}\text { Follow-up < } 12 \text { months } \\
19 \text { RCTs ( } 6000 \text { partici- } \\
\text { pants), }\end{array}$ & $\begin{array}{l}\text { Follow-up < } \\
\mathbf{1 2} \text { months } \\
25 \text { RCTs (1871 } \\
\text { participants) }\end{array}$ & $\begin{array}{l}17 \text { RCTs } \\
\text { (6852 par- } \\
\text { ticipants) }\end{array}$ & $\begin{array}{l}6 \text { RCTs ( } 2330 \text { partici- } \\
\text { pants) } \\
\text { RR } 0.79 ; 95 \% \text { Cl } 0.55 \\
\text { to } 1.13\end{array}$ & $\begin{array}{l}\text { Follow-up }<12 \\
\text { months } \\
7 \text { RCTs (1166 par- } \\
\text { ticipants) }\end{array}$ & $\begin{array}{l}3 \text { RCTs ( } 211 \\
\text { participants) } \\
\text { 0/3 RCTs re- } \\
\text { ported a sig- } \\
\text { nificant dif- }\end{array}$ \\
\hline
\end{tabular}


Table 10. Summary of outcome results across Cochrane systematic reviews (Continued)

\begin{tabular}{|c|c|c|c|c|c|c|}
\hline & $\begin{array}{l}\text { RR } 0.82 ; 95 \% \mathrm{Cl} 0.67 \text { to } \\
1.01 \\
\mathrm{I}^{2}=0 \% \\
\text { Follow-up > } 12 \text { months } \\
16 \text { RCTs ( } 5790 \text { partici- } \\
\text { pants) } \\
\text { RR } 0.87 ; 95 \% \mathrm{Cl} 0.75 \text { to } \\
0.99 \\
\mathrm{I}^{2}=0 \%\end{array}$ & $\begin{array}{l}\text { RR } 0.93 ; 95 \% \\
\text { Cl } 0.697 \text { to } \\
1.27 \\
\mathrm{I}^{2}=0 \% \\
\text { Follow-up > } \\
\mathbf{1 2} \text { months } \\
6 \text { RCTs (2845 } \\
\text { participants) } \\
\text { RR } 0.88 ; 95 \% \\
\text { Cl } 0.75 \text { to } 1.02 \\
\mathrm{I}^{2}=34 \%\end{array}$ & $\begin{array}{l}\text { RR 0.89; } \\
95 \% \mathrm{Cl} 0.75 \\
\text { to } 1.05 \\
\mathrm{P}^{2}=2 \%\end{array}$ & $\left.\right|^{2}=16 \%$ & $\begin{array}{l}\text { RR } 0.79 ; 95 \% \mathrm{Cl} \\
0.43 \text { to } 1.47 \\
\mathrm{I}=0 \% \\
\begin{array}{l}\text { Follow-up > } 12 \\
\text { months }\end{array} \\
1 \text { RCT ( } 525 \text { par- } \\
\text { ticipants) } \\
\text { RR } 1.99 ; 95 \% \mathrm{Cl} \\
0.50 \text { to } 7.88\end{array}$ & $\begin{array}{l}\text { ference be- } \\
\text { tween in- } \\
\text { tervention } \\
\text { and control } \\
\text { groups } \\
\text { (no pooling } \\
\text { of data) }\end{array}$ \\
\hline $\begin{array}{l}\text { Cardiovas- } \\
\text { cular mor- } \\
\text { tality }\end{array}$ & $\begin{array}{l}\text { Follow-up < } 12 \text { months } \\
9 \text { RCTs ( } 4130 \text { partici- } \\
\text { pants) } \\
\text { RR } 0.93 ; 95 \% \text { Cl } 0.71 \text { to } \\
1.21 \\
\mathrm{I}^{2}=0.0 \%\end{array}$ & $\begin{array}{l}\text { "Studies did } \\
\text { not consis- } \\
\text { tently report } \\
\text { deaths due to } \\
\text { heart failure or } \\
\text { sudden death" }\end{array}$ & $\begin{array}{l}5 \text { RCTs } \\
\text { (3893 par- } \\
\text { ticipants) } \\
\text { RR } 0.80 \text {; } \\
95 \% \mathrm{Cl} 0.6 \\
\text { to } 1.00 \\
\mathrm{I}^{2}=0.0 \%\end{array}$ & NR & NR & NR \\
\hline
\end{tabular}

Follow-up > 12 months

12 RCTs (4757)

RR $0.74 ; 95 \% \mathrm{Cl} 0.63$ to

0.87

$12=0 \%$

\begin{tabular}{|c|c|c|c|c|c|c|}
\hline $\begin{array}{l}\text { Hospitali- } \\
\text { sation }\end{array}$ & $\begin{array}{l}\text { Follow-up < } 12 \text { months } \\
4 \text { RCTs ( } 463 \text { partici- } \\
\text { pants) } \\
\text { RR } 0.69 ; 95 \% \text { Cl } 0.51 \text { to } \\
0.93 \\
\left.\right|^{2}=12 \% \\
\text { Follow-up > } 12 \text { months } \\
7 \text { RCTs ( } 2009 \text { partici- } \\
\text { pants) } \\
\text { RR } 0.98 ; 95 \% \text { Cl } 0.87 \text { to } \\
1.11 \\
\left.\right|^{2}=56 \%\end{array}$ & $\begin{array}{l}\text { Follow-up < } \\
\mathbf{1 2} \text { months } \\
15 \text { RCTs (1328 } \\
\text { participants) } \\
\text { RR 0.75; 95\% } \\
\text { Cl } 0.62 \text { to } 0.92 \\
\text { |2 = 0\% } \\
\text { Follow-up > } \\
\mathbf{1 2} \text { months } \\
5 \text { RCTs (2722 } \\
\text { participants) } \\
\text { RR } 0.92 ; 95 \% \\
\text { Cl } 0.66 \text { to } 1.29 \\
\text { |2 = 63\% }\end{array}$ & NR & $\begin{array}{l}\text { At end of follow-up } \\
\text { period } \\
4 \mathrm{RCTs}(12,905 \text { partic- } \\
\text { ipants) } \\
\text { RR } 0.83 ; 95 \% \mathrm{Cl} 0.65 \\
\text { to } 1.07 \\
\mathrm{I}^{2}=32 \%\end{array}$ & $\begin{array}{l}1 \mathrm{RCT} \\
\text { No difference } \\
\text { between home- } \\
\text { based and cen- } \\
\text { tre-based CR }\end{array}$ & $\begin{array}{l}3 \text { RCTs (num- } \\
\text { bers NR) } \\
\text { No signif- } \\
\text { icant dif- } \\
\text { ference be- } \\
\text { tween in- } \\
\text { tervention } \\
\text { and control } \\
\text { groups } \\
\text { (no pooling } \\
\text { of data) }\end{array}$ \\
\hline $\begin{array}{l}\text { HF-specific } \\
\text { admissions }\end{array}$ & NR & $\begin{array}{l}\text { Follow-up > } \\
\mathbf{1 2} \text { months } \\
12 \mathrm{RCTs} \text { (1036 } \\
\text { participants) }\end{array}$ & NR & $\begin{array}{l}1 \mathrm{RCT} \\
\text { Participants in the in- } \\
\text { tervention group had } \\
41 \% \text { fewer ( } \mathrm{P} \text { value } \\
=0.05 \text { ) and } 61 \% \text { few- }\end{array}$ & NR & NR \\
\hline
\end{tabular}


Table 10. Summary of outcome results across Cochrane systematic reviews (Continued)

RR 0.61; 95\%

$\mathrm{Cl} 0.46$ to 0.80

$12=34 \%$ er heart-related inpa-

tient days

$(P$ value $=0.02)$ than

in the control group

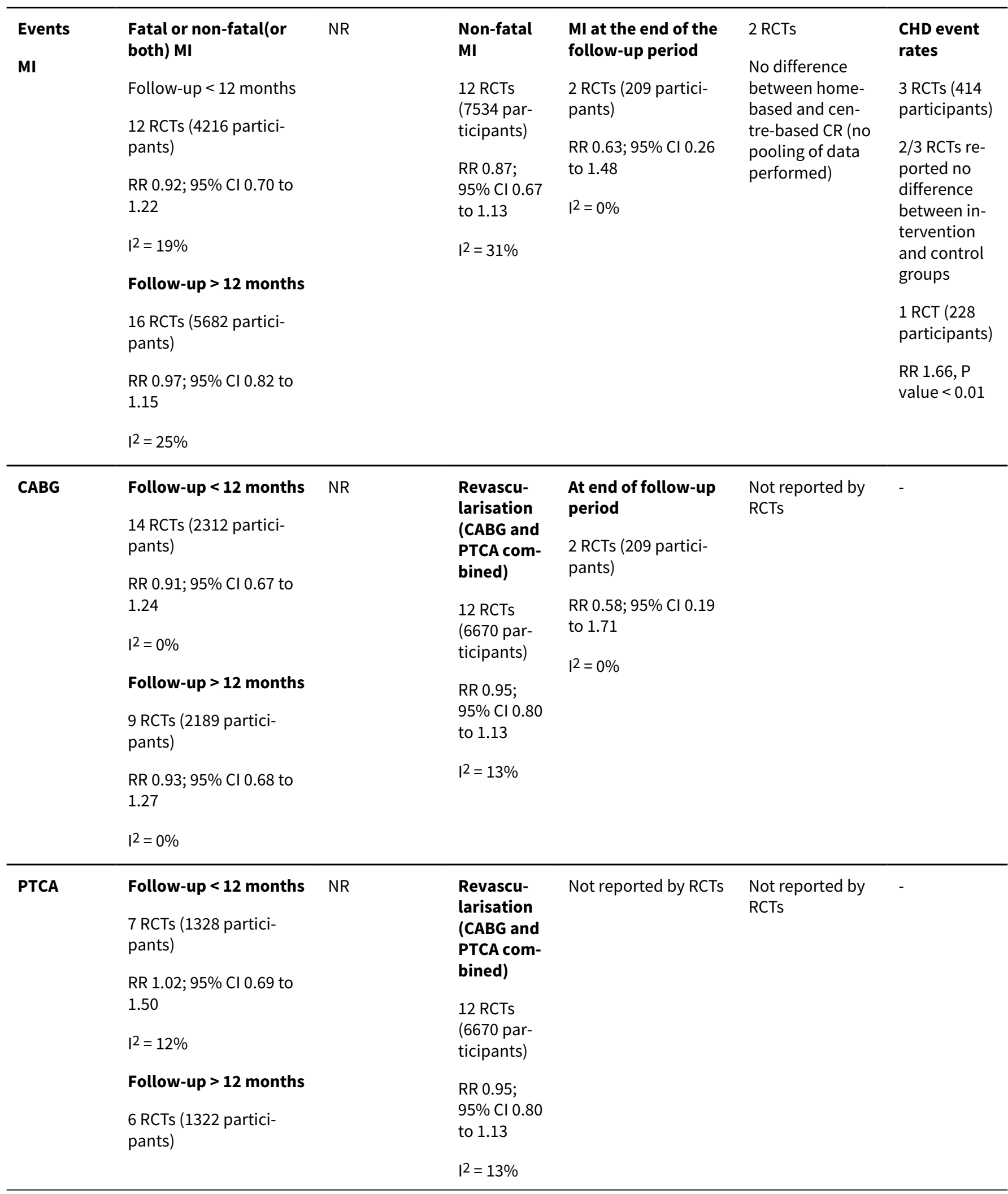


Table 10. Summary of outcome results across Cochrane systematic reviews (Continued) RR $0.89 ; 95 \% \mathrm{Cl} 0.66$ to

1.19

$12=20 \%$

\begin{tabular}{|c|c|c|c|c|c|c|}
\hline HRQOL & $\begin{array}{l}10 \text { RCTs } \\
7 / 10 \text { RCTs reported ev- } \\
\text { idence of a significant- } \\
\text { ly higher level of HRQoL } \\
\text { with intervention at fol- } \\
\text { low-up }\end{array}$ & 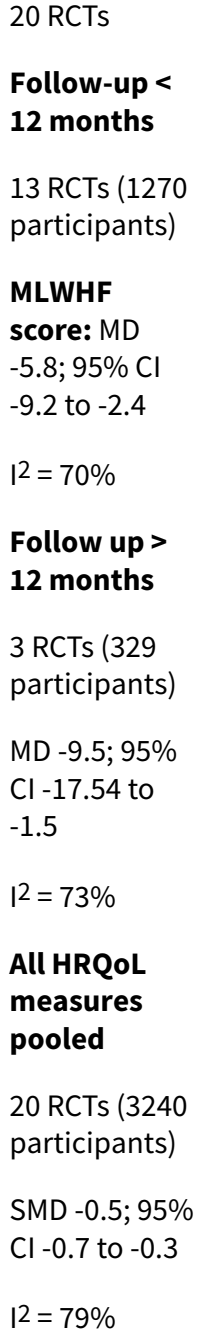 & $\begin{array}{l}7 \text { RCTs } \\
1 / 7 \text { RCTs } \\
\text { reported } \\
\text { evidence } \\
\text { of a signifi- } \\
\text { cantly high- } \\
\text { er level of } \\
\text { HRQoL with } \\
\text { interven- } \\
\text { tion at fol- } \\
\text { low-up }\end{array}$ & $\begin{array}{l}\text { Across } 11 \text { RCTs, } 81 \\
\text { HRQoL outcome } \\
\text { scores/sub-scores re- } \\
\text { ported: } \\
\text { 14/81 in favour of in- } \\
\text { tervention compared } \\
\text { to control } \\
67 / 81 \text { no significant } \\
\text { difference between } \\
\text { intervention and } \\
\text { control } \\
\text { 5/11 RCTs reported } \\
\text { evidence of a signif- } \\
\text { icantly higher level } \\
\text { of some HRQoL do- } \\
\text { mains with interven- } \\
\text { tion at follow-up } \\
\text { No consistent differ- } \\
\text { ence in HRQoL total } \\
\text { or domain score at } \\
\text { follow-up between } \\
\text { intervention and } \\
\text { control }\end{array}$ & $\begin{array}{l}10 \text { RCTS } \\
\text { 8/10 RCTs re- } \\
\text { ported improve- } \\
\text { ments in HRQoL } \\
\text { at follow-up } \\
\text { with both home- } \\
\text { based and cen- } \\
\text { tre-based CR } \\
\text { compared with } \\
\text { baseline } \\
\text { No strong evi- } \\
\text { dence of differ- } \\
\text { ence in over- } \\
\text { all HRQoL out- } \\
\text { comes or do- } \\
\text { main score at fol- } \\
\text { low up between } \\
\text { home-based and } \\
\text { centre-based CR }\end{array}$ & $\begin{array}{l}2 \text { RCTs } \\
1 / 2 \text { RCTs re- } \\
\text { ported im- } \\
\text { provement } \\
\text { in HRQoL } \\
\text { with inter- } \\
\text { vention (not } \\
\text { significant) } \\
1 / 2 \text { RCTs } \\
\text { reported } \\
\text { improve- } \\
\text { ment in both } \\
\text { groups but } \\
\text { no signif- } \\
\text { icant dif- } \\
\text { ference be- } \\
\text { tween inter- } \\
\text { vention and } \\
\text { control }\end{array}$ \\
\hline $\begin{array}{l}\text { Economics } \\
\text { Costs } \\
\text { Cost-effec- } \\
\text { tiveness }\end{array}$ & $\begin{array}{l}\text { Costs } \\
3 \text { RCTs } \\
2 / 3 \text { studies reported } \\
\text { total healthcare costs } \\
\text { were not statistically } \\
\text { significantly different } \\
\text { between groups } \\
\text { Cost-effectiveness } \\
1 \text { RCT } \\
\text { Authors concluded that } \\
\text { rehabilitation was an } \\
\text { efficient use of health- } \\
\text { care resources and may } \\
\text { be economically justi- } \\
\text { fied }\end{array}$ & $\begin{array}{l}3 \text { RCTs } \\
2 \text { studies un- } \\
\text { dertook a cost } \\
\text { effectiveness } \\
\text { analysis and } 1 \\
\text { reported costs } \\
\text { There was no } \\
\text { evidence of } \\
\text { significantly } \\
\text { different costs } \\
\text { or outcomes }\end{array}$ & NR & $\begin{array}{l}5 \text { RCTs reported } \\
\text { healthcare utilisation } \\
\text { costs } \\
2 / 5 \text { RCTs reported } \\
\text { an overall mean net } \\
\text { saving of USD965 } \\
\text { per participant at } 6 \\
\text { months follow-up } \\
\text { and USD1420 per } \\
\text { participant at } 24 \\
\text { months follow-up } \\
\text { 1/5 RCTs reported an } \\
\text { increase in mean net } \\
\text { costs of USD52 per } \\
\text { participant }\end{array}$ & $\begin{array}{l}\text { 3/4 RCTs re- } \\
\text { ported health- } \\
\text { care costs as- } \\
\text { sociated with } \\
\text { CR were lower } \\
\text { for the home- } \\
\text { based than cen- } \\
\text { tre-based pro- } \\
\text { grammes } \\
1 / 4 \text { RCTs report- } \\
\text { ed that home- } \\
\text { based CR was } \\
\text { more costly than } \\
\text { centre-based CR } \\
\text { but costs would } \\
\text { be the same if } \\
\text { participant trav- } \\
\text { el costs and trav- }\end{array}$ & NR \\
\hline
\end{tabular}


Table 10. Summary of outcome results across Cochrane systematic reviews (Continued) 2/5 RCTs reported no difference between

el time were ingroups

No RCTs reported cost-effectiveness cluded

8 studies reported different aspects of consumption of healthcare resources

No significant between group differences were seen

\begin{tabular}{|c|c|c|c|c|c|c|}
\hline $\begin{array}{l}\text { All-cause } \\
\text { withdraw- } \\
\text { al/drop- } \\
\text { out at fol- } \\
\text { low-up }\end{array}$ & NR & NR & NR & $\begin{array}{l}\text { At follow-up } \\
8 \text { RCTs ( } 2862 \text { partici- } \\
\text { pants) } \\
\text { RR } 1.03 ; 95 \% \mathrm{Cl} 0.83 \\
\text { to } 1.27 \\
12=34 \%\end{array}$ & $\begin{array}{l}\text { At follow-up } \\
18 \text { ( } 1894 \text { partici- } \\
\text { pants) } \\
\text { RR } 1.04 ; 95 \% \mathrm{Cl} \\
1.00 \text { to } 1.08 \\
\mathrm{I} 2=44 \%\end{array}$ & NR \\
\hline Uptake & NR & NR & NR & NR & NR & $\begin{array}{l}10 \text { RCTs } \\
\text { (1338 partici- } \\
\text { pants) } \\
\text { 8/10 RCTs re- } \\
\text { ported up- } \\
\text { take was sig- } \\
\text { nificantly } \\
\text { higher in in- } \\
\text { tervention } \\
\text { group }\end{array}$ \\
\hline Adherence & NR & NR & NR & NR & $\begin{array}{l}14 \text { RCTs } \\
\text { *3/14 RCTs re- } \\
\text { ported adher- } \\
\text { ence was signifi- } \\
\text { cantly higher in } \\
\text { home-based CR }\end{array}$ & $\begin{array}{l}8 \text { RCTs ( } 1150 \\
\text { participants) } \\
\text { 3/8 RCTs re- } \\
\text { ported ad- } \\
\text { herence was } \\
\text { significant- } \\
\text { ly higher in } \\
\text { intervention } \\
\text { group }\end{array}$ \\
\hline
\end{tabular}

CABG: coronary artery bypass graft; CHD: coronary heart disease; CR: cardiac rehabilitation; HF: heart failure; HRQoL: health-related quality of life; MD: mean difference; MI: myocardial infarction; MLWHF: Minnesota Living with Heart Failure questionnaire; NR: not reported; PTCA: percutaneous transluminal coronary angioplasty; RCT: randomised controlled trial; RR: risk ratio; SMD: standardised mean difference.

${ }^{*}$ As reported in the 'Summary of findings' table. Effects of interventions section states 4/14.

\section{AP PE N DICES}

\section{Appendix 1. Search strategy}

\section{The Cochrane Library}

\#1 cardiac near/4 rehab* 
\#2 cardiac near/4 exercise*

\#1 OR \#2

Appendix 2. Excluded systematic reviews

\begin{tabular}{lll}
\hline Author & Title & Reason for exclusion from overview \\
\hline Hulzebos 2012 & $\begin{array}{l}\text { Preoperative physical therapy for } \\
\text { elective cardiac surgery patients }\end{array}$ & $\begin{array}{l}\text { Only 1/8 included randomised controlled trials compared cardiores- } \\
\text { piratory exercise training with a non-exercise control }\end{array}$ \\
\hline
\end{tabular}

Appendix 3. Protocols identified

\begin{tabular}{ll}
\hline Author & Title \\
\hline Devi 2011 & Internet-based interventions for the secondary prevention of coronary heart disease \\
\hline Euler 2013 & Interventions to support return-to-work for patients with coronary heart disease \\
\hline *Mechta-Nielsen 2014 & Exercise-based cardiac rehabilitation for adult patients with ICD \\
\hline Risom 2014 & Exercise-based cardiac rehabilitation for adults with atrial fibrillation \\
\hline Sibilitz 2013 & Exercise-based cardiac rehabilitation for adults after heart valve surgery \\
\hline
\end{tabular}

*We are aware of this proposed title through personal communication with the authors.

\section{WHAT'S NEW}

\begin{tabular}{lll}
\hline Date & Event & Description \\
\hline 22 December 2021 & Amended & $\begin{array}{l}\text { The editorial team, in agreement with the lead author Rod Tay- } \\
\text { lor, have decided that no update of this review is needed cur- } \\
\text { rently as the topic is covered sufficiently in recent non-Cochrane } \\
\text { publications. }\end{array}$ \\
& & \\
\hline
\end{tabular}

\section{H I S T O R Y}

Protocol first published: Issue 8, 2014 Review first published: Issue 12, 2014

\section{CONTRIBUTIONS OF AUTHORS}

Both authors were involved in the conception and design of the protocol and the review; undertook the study selection, data extraction and risk of bias assessment; and drafted the manuscript.

\section{DECLARATIONS OF INTEREST}

Rod Taylor was a co-author on five of the included systematic reviews.

Lindsey Anderson has no known conflict of interest. 


\section{SOURCES OF SUPPORT}

\section{Internal sources}

- University of Exeter Medical School, UK

\section{External sources}

- No sources of support provided

\section{DIFFERENCES BETWEEN PROTOCOLAND REVIEW}

There were no differences between the protocol and the review.

\section{INDEX TERMS}

\section{Medical Subject Headings (MeSH)}

Coronary Disease [ ${ }^{\star}$ rehabilitation]; Exercise Therapy [ ${ }^{\star}$ methods]; Heart Failure [ ${ }^{\star}$ rehabilitation]; Myocardial Infarction [rehabilitation]; Percutaneous Coronary Intervention [ ${ }^{\star}$ rehabilitation]; Randomized Controlled Trials as Topic; Review Literature as Topic

\section{MeSH check words}

Humans 